\title{
Současné politické konflikty v oblasti Afrického rohu
}

\author{
ALEMAYEHU KUMSA*
}

Political Conflicts in Contemporary Horn of Africa

\begin{abstract}
Violent conflict is very old in human society. The development of military technology brought with itself the worst tragedies loss of human live and material devastation in the second half of 20th century in the Horn of Africa. This region is one of the centers of various political violent conflicts in the world, according to length of these violent conflicts, the number of death of people, mainly civilian, refugees and internal displaced persons (IDP). This study elucidates the root causes of long wars in the Horn of Africa focusing mainly on South Sudan and Somalia. It also illustrates how the Super Powers during the Cold War helped their client states to prolong the suffering of people in the region. When Socialist system disappeared from Eastern Europe, Mengistu Haile Mariam's and Siyad Barre's regime ignominiously collapsed. In Ethiopia Amhara power elite, who ruled the Empire state from 1889 to 1991 lost their state power and Tigrian guerrilla fighters captured it through the power of the gun, Eritrea gained its independence from Ethiopia, South Sudan is emerging from long heinous war to independence. The violent conflict in Somalia transformed after the old regime demise in 1991 and the new leaders unable to build new central government. Somalia is fragmented and became the good example of failed state in the theory of contemporary political sociology. The paper tries to explain these complex violent conflicts in this part of Africa.
\end{abstract}

Key words: political conflicts, Horn of Africa, Ethiopia, Somalea, Kenya, war, geopolitical strategy.

\section{Přehled politických konfliktů v oblasti Afrického rohu}

Africkým rohem se v tomto článku rozumí část severovýchodní Afriky zahrnující státy Eritrea, Etiopie, Džibuti, Keňa, Somálsko a Súdán. Tento africký region je nejžhavější konfliktní zónou na světě a některé $\mathrm{z}$ nejzuřivějších válek druhé poloviny 20 . století rozdělily oblast na jednotlivé části. ${ }^{1} \mathrm{Ti}$, kdo v těchto válkách a obtížích $\mathrm{z}$ nich vzešlých trpěli nejvíc, pocházeli z řad civilního obyvatelstva zemědělských oblastí; jednalo se zejména o ženy a děti. Podle jedné studie publikované v roce 1999 „v průběhu třiceti let konfliktů a hladomoru v Africkém rohu zemřelo podle odhadu mezi 15 až 20 miliony lidí, což je číslo, které je ve srovnání s velikostí populace proporčně vyšší než počet osob, které přišly o život během druhé světové války“.2 Středisky těchto vražedných konfliktů přitom byly tři státy regionu. Prvním ze států představujících jádra konfliktů je Súdán, největší země afrického kontinentu s rozlohou $2505813 \mathrm{~km}^{2}$ a počtem obyvatel $43939598 .^{3}$

Konflikt v Súdánu, který má své počátky na jihu tohoto státu, se vyznačuje spletitým, vnitřně vzájemně provázaným charakterem; vleklý boj mezi vládou v Chartúmu

\footnotetext{
PhDr. Alemayehu Kumsa, Ph.D., Ústav etnologie, Filozofická fakulta, Univerzita Karlova, nám. Jana Palacha 2, 11000 Praha 1.E-mail: alemayehu.kumsa@ff.cuni.cz

1 Prendergast \& Thomas-Jensen [2007: 59].

2 Wodajo [1999: 104].

3 Fact book [červenec 2010].
} 
ovládanou Araby a jižním Súdánem zastoupeným Afričany stál v druhé válce od 1983 do roku 2005 životy více než dva miliony obyvatel jižního Súdánu. ${ }^{4}$ Počínaje získáním nezávislosti na Velké Británii v roce 1956 až do konce války na jihu země v roce 2005 tak zažil Súdán jako nezávislý stát mír pouze po dobu jedenácti let - mezi lety 1972 a 1983.

Ještě než skončila válka na jihu, vypukl v Darfuru (západní část státu) roku 2003 další smrtící konflikt mezi původními obyvateli oblasti a vládou podporovanými a organizovanými, cvičenými a vyzbrojenými arabskými milicemi. Tento konflikt stál životy 200 až 450 tisíc lidí; 2,5 milionu osob bylo vyhnáno z domovů a dvě třetiny všech obyvatel Darfuru - zhruba 4,3 milionů lidí - zůstává v současné době odkázáno na ten či onen druh humanitární pomoci. Tato válka byla ze strany súdánské vlády zaměřena proti domorodým obyvatelům Darfuru, a to s cílem vyhnat je z jejich domoviny a na jejich místo usadit Araby ze severního Súdánu. 9. září 2004 ji bývalý státní tajemník USA Collin Powell označil před senátním výborem USA pro zahraniční vztahy za "genocidu“. 5 Situace se uklidnila díky úsilí vynaloženému Africkou unií, Evropskou unií a Spojenými národy a Smlouva o míru v Darfuru (Darfur Peace Agreement - DPA) byla podepsána súdánskou vládou a Súdánskou osvobozeneckou armádou (Sudan Liberation Army) v Abuja (Nigérie) 5. května 2006. Tato smlouva mezi súdánskou vládou a jednou ze skupin povstalců stanovila rámec pro mír, bezpečnost, obnovu a správu - věci, jež Darfur od svého začlenění do Súdánu nezažil. ${ }^{6}$ Ostatní skupiny, které Smlouvu o míru v Darfuru odmítly podepsat, pokračovaly v boji s vládní armádou a konflikt se posléze rozšíril do Čadu a Středoafrické republiky - důsledkem toho bylo, že další dva miliony obyvatel v zasažených zemích potřebovaly humanitární pomoc. Súdánská vláda zároveň podporuje povstalecké skupiny a milice $\mathrm{v}$ obou státech $\mathrm{v}$ naději, že se tak podaří svrhnout jejich vlády a nastolit $\mathrm{v}$ nich "přátelššejší “ režimy. ${ }^{7}$

Třetím místem konfliktu v Súdánu je pobřežní oblast Rudého moře obývaná národem Bedža; jeho př́íslušníci se chopili zbraní proti Chartúmu proto, že jejich region byl v rámci hospodářského rozvoje země opomíjen.

Další klubko konfliktů má svůj střed v Somálsku a týká se rovněž Etiopie, Eritrey a severovýchodní Keni. Somálsko přitom zůstává jedinou zemí na světě bez fungující vlády, a to od roku 1991, kdy byl svržen vojenský diktátor země Siyad Barre. Opoziční skupiny, které byly schopné odstranit jednoho z nejhorších porušovatelů lidských práv v Africe, nedokázaly vytvořit ústřední vládu, protože zakládaly své principy spíše na klanové než národní jednotě somálského lidu ${ }^{8}$, což vedlo k rozdrobení země do tří klanových území - na tzv. Republiku Somálsko (Republic of Somaliland), Oblastní stát Puntland (Regional State of Puntland) a Oblast válečníků jižního Somálska (Warlords' Area of Southern Somalia).

Republika Somálsko, bývalé britské Somálsko, vyhlásila svou nezávislost v květnu 1991 a vyvázala se tak ze svazu Somálské republiky vytvořené spolu s Italským Somálskem 1. července 1960; do dnešního dne ji však žádná oblastní či mezinárodní vládní organizace nebo stát neuznaly jako státní jednotku. ${ }^{9}$ Severovýchodní oblast země obývaná klanem

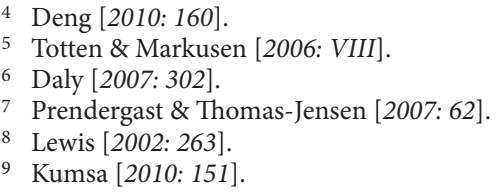


(subklanem) Majerteen z Darodu vyhlásila svou regionální autonomii roku 1998 a od té doby má v rukou dozor nad touto oblastí. Jižní část země zahrnující Mogadišo se stala jevištěm mnoha soupeřících vnitřních i vnějších (zahraničních) zájmů bez jakékoliv vládní struktury a v moderních dějinách se stala příkladem státu, který selhal. ${ }^{10}$

Poslední centrum konfliktů představuje Etiopie, kde se nejdelší střet odehrával v Eritreji od roku 1961 do roku 1991. Eritrea pak získala nezávislost na Etiopii v roce 1991, kdy byli z provincie vyhnáni poslední př́slušníci etiopské armády a k moci se na dva roky dostala Eritrejská fronta národního/lidového osvobození (Eritrean Peoples Liberation Front - EPLF); ve dnech 23.-25. dubna 1993 zorganizovala referendum, v němž se „99,8\% hlasujících vyjádřilo pro nezávislost “. ${ }^{11}$ Tak se uzavřela jedna z kapitol nejdelší krvavé války v Africe. Prvním státem, který uznal nezávislost Eritrey, byla Etiopie, ovšem jedním z prvních kritérií nezávislého státu je vymezení hranic země demarkací. ${ }^{12}$ Noví vůdci obou zemí byli přátelé, kteří připravili společnou strategii jak odstranit etiopský diktátorský režim Mengistu Haile Mariama, svrženého nakonec v květnu 1991. Vůdci jak Eritrejské fronty národního/lidového osvobození (Eritrean Peoples Liberation Front - EPLF), tak Tigrejské fronty národního/lidového osvobození (Tigrai People’s Liberation Front - TPLF) byli příslušníky národa Tigrai, měli tedy stejný původ, hovořili stejným jazykem, vyznávali stejné náboženství a pocházeli z Habešského království. ${ }^{13}$

Když se tito politici dostali k moci, mnoho lidí si myslelo, že vztah mezi oběma zeměmi bude založen na dobré víře a vytvoří podmínky pro blaho Eritrejců i Etiopanů. Tento vztah byl bezproblémový až do roku 1997, ale pak se znovu rozhořel konflikt kvưli hranicím. Není bez zajímavosti, že lidé v bojem zasažených hraničních oblastech jsou Tigrejci podobně jako oba vůdci těchto zemí. Válka propukla v roce 1998 právě kvưli hranicím, což způsobilo jen na etiopské straně v letech 1998-2000 smrt cca 123000 bojovníků, ${ }^{14}$ přičemž otázka hranic mezi oběma zeměmi zůstala nevyřešena. Tlak ze strany vlády USA a Africké unie přinutil vůdce Etiopie a Eritrey obrátit se k Mezinárodnímu soudnímu dvoru v Haagu se žádostí o arbitráž v daném konfliktu. V rámci Alžírské mírové smlouvy se navíc shodli na tom, že rozhodnutí soudního dvora bude konečné a zavazující. ${ }^{15}$ Když však soudní dvưr rozhodl, že sporné území náleží Eritreji, odmítla etiopská vláda toto rozhodnutí přijmout a až dosud jsou armády obou znesvářených zemí na obou stranách hranic v nejvyšším stupni pohotovosti; nikdo neví, kdy tento - podle řady odborníků na válečné konflikty africký model připomínající první světovou válku - znovu začne. ${ }^{16}$ Etiopie má v rámci svého území otevřenu i další válečnou frontu, konkrétně namířenou proti dvěma národním osvobozeneckým frontám. V rámci moderní africké historie představuje Etiopie zvláštní stát, protože vyjma let 1935-1941, kdy ji okupovala Itálie, nebyla nikdy kolonizována žádnou z evropských ř́ší. Etiopie je nástupcem Habešského království, které se na konci 19. století podílelo spolu s dalšími koloniálními velmocemi Západní Evropy na kolonizování afrických států, tedy svých vlastních sousedů. Habeš tak dobyla a kolonizovala národy

\footnotetext{
10 Ndulo [2010: 26-27].

11 Iyob [1995: 140].

12 Mann [1984: 188, 2007: 37], Kumsa [1992: 10].

13 Negash \& Tronvoll [2000: 10]. Habešské království je původní území Habeše před expanzí na konci 19. století, po které získal Menilek II. titul habešského císaře.

14 Sagalee Haaraa [No. 33: S. 14].

15 Agreement between Eritrea \& Ethiopia [12. 12. 2000].

16 Negash a Tronvoll [2000: 1].
} 
kušitských a nilotických skupin, jako jsou Oromo, Afar, část Somálců, Sidama, Kaficho a další. ${ }^{17}$ Rozloha království se zčtyřnásobila a král Menelik II přejmenoval svou novou říši na Etiopii. Národy, které se ocitly pod jhem Habeše, se zorganizovaly s cílem osvobodit se podobně jako jejich afričtí bratři vymaňující se z evropské koloniální nadvlády. Hlavními úctu vzbuzujícími silami v současné Etiopii jsou Oromská osvobozenecká fronta (Oromo Liberation Front - OLF) a Ogadenská národní osvobozenecká fronta (Ogaden National Liberation Front - ONLF), které bojují na domácí půdě v regionech Oromo a Ogaden v jihovýchodní Etiopii. Podle politických programů obou osvobozeneckých front je jejich záměrem vybudovat Demokratickou republiku Oromiyya a Republiku Ogadenia.

Přesuňme nyní svoji pozornost do Keni, považované za východoafrický ekonomický „parostroj“ (hnací motor), stabilní stát v nestabilním regionu, který poskytuje útočiště mnoha tisícům uprchlíků z konfliktních oblastí Etiopie, Súdánu, Severní Ugandy a Somálska. Avšak rovněž Keňa má svůj vlastní politický problém, jehož kořeny leží v dobách britské koloniální vlády, která vyhnala př́íslušníky národa Gikuyu (Kikuyu) z nejúrodnější země teritoria, a to ve prospěch osadníků $\mathrm{z}$ Británie. ${ }^{18} \mathrm{~V}$ Africe má každý národ ${ }^{19}$ své vlastní území a v mnoha oblastech zůstává půda společným vlastnictvím komunity, jež danou oblast po staletí okupuje. Proto když britská koloniální správa usadila příslušníky Gikuyu v zemi Masajů a na dalších územích, byli tam považováni za vetřelce, kteří přišli, aby se zmocnili jejich země. ${ }^{20}$ Gikuyové jako zemědělci navíc mají zvláštní vztah k půdě, jak to pozorovala autorka zabývající se politikou koloniálního osídlování v Keni: „Gikuyu by bez půdy nemohl být Gikuyou. “21 Když Keňa získala nezávislost, noví vůdci neřešili problém vlastnictví půdy, který tak představuje hlavní konflikt mezi národy žijícími v Keni. Gikuyu je v Keni největším (nejpočetnějším) národem a první prezident Keni Jomo Kenyatta, jenž tuto funkci zastával v letech 1964-1978, pocházel právě z tohoto národa. Moc se pak přesunula z rukou národa Gikuyu k národu Kalenjin ve chvíli, kdy se Daniel Arap Moi (prŕíslušníka národa Kalenjin), viceprezident během prezidentství Kenyaty, který zemřel ve svém úřadu v roce 1978, stal v době od roku 1978 do roku 2002 prezidentem. Konflikt mezi příslušníky Gikuyu a ostatními skupinami propukl v roce 1992, kdy bylo mnoho jednotlivců z toho národa zabito a vyhnáno ze západní Keni z půdy Masajů, a znovu se rozhořel také během voleb v letech 2002 a 2007-2008.22

\section{Základní příčiny politických konfliktů v jižním Súdánu}

Nejdelší a nejkrvavější konflikt v Súdánu se rozhořel mezi obyvateli jižního Súdánu a súdánskou vládou; došlo k tomu rok před získáním nezávislosti země v roce 1956. Konflikt, který vypukl na konci britské koloniální éry, má hluboké kořeny v dějinách této oblasti a souvisí s procesem arabizace severní Afriky. Severní a střední část Súdánu byla jedním z prvních států, jež byly v pátém století obráceny na křest̉anství, a jedním z nejstarších regionů na světě, kde se v dějinách lidstva začaly budovat státy. Státotvorný proces začal

\footnotetext{
17 Bulatovich [1900/2000: 12], Martial de Salviac [1901/2005: 351-55], Pankrhust [1968: 73-134], Bulcha [2002: 72].

18 Elkins [2005: 14-15].

19 Achebe [2003: 5].

20 Chege [2008: 134].

21 Elkins [2005: 14].

22 Human Rights Watch [2008: 11-12].
} 
po 3. tisíciletí př. Kr. a k nejznámějším a největším státům v oblasti patřilo království Kerma s hlavním městem Kerma v oblasti nilské delty a menší stát s hlavním městem Sai, ležící mezi Kermou a Egyptem. Kerma zhruba v 18. stol. př. Kr. dobyla království Sai, a zmocnila se tak celé střední a severní části současného Súdánu, čímž se stala největším státem jižně od Egypta. ${ }^{23}$ Křestanství bylo v roce 543 zavedeno také v Dongole, posledním království regionu, a přispělo $\mathrm{v}$ mnoha ohledech ke kulturnímu rozvoji jeho lidu. Budování nových kostelů a klášterů s sebou přineslo nové architektonické prvky v rámci rozvoje oblasti. Tyto křestanské státy žily se svým novým náboženstvím až do doby, kdy došlo k arabským muslimským výbojům (první z nich zasáhl Egypt mezi roky 639 až 642);24 islám se pomalu rozšířil po celé severní Africe a svou expanzi posléze obrátil na jih. Lidé ze severního Súdánu odolávali invazi beduínských Arabů, kteří v roce 1054 obsadili celou severní Afriku, nicméně postupná konverze $\mathrm{k}$ islámu a infiltrace Arabů na jejich území měla za následek konec období křestanských králů, takže po posledním z nich nastoupil v roce 1315 na trůn muslimský vládce. ${ }^{25}$ Jen na jihu odolávalo arabskému pronikání až do roku 1504 křestanské království Alwa, které nakonec podlehlo muslimskému státu Funj ze Sennaru. „To odstranilo poslední bariéru ležící v cestě beduínské expanzi v této části Afriky, a Baggarové či dobytkářští Arabové proudili na jih a západ do východního a středního Súdánu. " ${ }^{26}$ Tento trend pokračuje až dodnes zejména v Darfuru, přičemž cílem Arabů je vyhnat domorodé Afričany z jejich domoviny a na jejich místě usadit Araby ze severního Súdánu.

Samotný Súdán se stal největší zemí afrického kontinentu a jeho území se rovná zhruba velikosti západní Evropy. Hlavním jazykem na severu je arabština, zatímco na jihu mluví nejvíce obyvatel jazykem Dinka - prŕíslušníci tohoto národa tvoří nejpočetnější skupinu obyvatel v celé zemi a v jižním Súdánu. Co se složení obyvatel Súdánu týče, $65 \%$ je Afričanů a $35 \%$ Arabů (Arabové a arabizovaní Afričané); více než $70 \%$ Súdánců tvoří muslimové, z nichž největší podíl mají muslimové afrického původu. Většina zbývajících obyvatel vyznává tradiční náboženství, z tohoto počtu pak je 5-10\% kř̌estanů. ${ }^{27}$

Jižní Súdán tvoří tři provincie: Horní Nil, Bahr el Ghazal a Rovníkový Súdán. Jedná se o území představující jednu čtvrtinu celkové rozlohy Súdánské republiky a počet obyvatel jižního Súdánu je odhadován na jednu třetinu celé populace země. Hranice jižního Súdánu a sousedních zemí (Etiopie, Keni, Ugandy, Zaire a Středoafrické republiky) byly určeny libovolně imperiálními mocnostmi, které Súdán a jeho sousedy kolonizovaly. A tak se stalo, že některé národy v jižním Súdánu se „přelévají přes hranice do sousedních zemí. ${ }^{28}$ Expanze Arabů a islámu pokračovala jiným způsobem, když v roce 1820 Muhammad Ali, vládce Osmanské provincie v Egyptě, dobyl celý Súdán; důvodem bylo súdánské zlato a otroci - př́ští vojáci. Egyptský zábor a panství nad tímto územím byly posledním odvážným činem zástupců osmanské velmoci a turecko-egyptská koloniální vláda skončila po 60 letech, když ji v roce 1885 vyhnalo z ovládaného území mahdistické muslimské povstání. ${ }^{29}$ Bylo to rovněž v tomto období 19. století, konkrétně za turecko-egyptské vlády, kdy začalo roz-

\footnotetext{
${ }^{23}$ Ehret [2002: 149].

24 Ilifee [2001: 58].

${ }^{25}$ Murdock [1959: 160].

${ }^{26}$ Murdock [1959: 160].

27 International Crisis Group [2002: 5].

28 Wai [1973: 7].

${ }^{29}$ Hill [1959: $v$ ].
} 
dělení Súdánu na severní a jižní. Tato epocha proslula dramatickou expanzí otrokářských výprav zaměřených na získávání otroků v jižním Súdánu, přičemž cílem těchto nájezdů byli pouze nemuslimští obyvatelé jižního Súdánu, protože islám zakazuje mít muslimské otroky. Koloniální vláda spolupracovala při otrokářských výpravách do nemuslimských území s některými arabskými vlastníky půdy, kteří se podíleli na oficiálních nájezdech armády nebo organizovali své vlastní výpravy. „Přespočetné otroky si nájezdníci ponechávali pro svou vlastní potřebu nebo na prodej. Nejenže se za turecko-egyptského panství zvýšil počet otroků, ale rovněž se rozšírilo i jejich využívání, kdy se domácí otroctví poprvé rozšírílo ve všech segmentech společnosti severního Súdánu. “" $\mathrm{Na}$ vykořistování jihu se společně podílela sít vojenská i obchodní a vláda a obchodní společnosti měly své vlastní armády složené ze směsi svobodných mužů a otroků. Obě složky založily řadu opevněných obchodních center a po karavanních stezkách se dopravovali mladí muži a ženy z jihu jako otroci určení pro trhy na severu a Středním Východě. Obchodníci a vládní úředníci si na jihu vytvářeli také svá vlastní poddanská území coby zdroj otroků a bohatství země. V turecko-egyptském období pocházela populace otroků na severu z velké cásti z jižního Súdánu; v očích obyvatel severního Súdánu byli otroci a „černí synonymy. ${ }^{31}$ Dokonce i jižní Súdánci, kteří přestoupili na islám nebo pracovali v koloniální správě - což ti v armádě určitě byli -, byli stigmatizováni svým statutem otroka nebo otrockým původem. Výsledkem turecko-egyptského kolonialismu spojujíćího celý jižní Súdán se severem se tak stalo to, že určil obyvatelům jihu nižší statut oproti těm ze severu.

Turecko-egyptská koloniální vláda byla nakonec svržena islámským tzv. mahdistickým hnutím vedeným charismatickým náboženským vůdcem Muhammadem Ahmadem (Mahdí - očekávaný spasitel); vznikl mahdistický stát (1883-1898). Po smrti Mahdího založil jeho nástupce Khalifa Abdallahi svou autokratickou vládu z velké části na existující armádě otrokủ, kteří pocházeli hlavně z jihu a ze západu. Mahdistický stát následně rozšíriil svou moc směrem na jih - důvodem byli otroci a zemědělské produkty. Velký hladomor z let 1888-92 zvýšil počty nájezdů na jih, tentokrát s cílem plenit, rabovat, a získávat potraviny a více otrokủ, a obnovit tak zmenšující se zdroje pro domácí práci a vojenské odvody. Mahdistický stát rozdělil obyvatele oblasti mezi dár al-islam (domov míru), tedy ty, kteří přijali islámskou víru, a dár al-harb (domov války), tedy takové, kteří vyznávali tradiční africká náboženství. Toto rozdělení nabylo ostřejších forem než kdy dříve a vyústilo ve válku namířenou proti neislámské populaci, opět kvưli otrokủm a rabování.

Mahdistický stát rozvinul svou vlastní formu vnitřního kolonialismu v jižním Súdánu. ${ }^{32}$ Přepokládá se, že populace Súdánu klesla ze 7 milionů před mahdistickou revoltou v 19. století na přibližně 2 až 3 miliony po rozpadu mahdistického státu. ${ }^{33}$ Rasové postoje těch obyvatel ze severu vůči těm $z$ jihu se přitom nezměnily. Mahdistický stát eliminoval tradiční systém vlády a nahradil jej př́mým vládnutím (Direct rule), tj. jmenováním správců nebo zmocněnců, kteří měli spravovat zemědělské oblasti na jihu, západě a východě. To je jedním $\mathrm{z}$ důvodů, proč došlo $\mathrm{v}$ roce $1898 \mathrm{k}$ anglo-egyptskému svržení mahdistického státu za pomoci zvláštních skupin, které se stavěly proti útlaku ze strany této islamistické vlády. Historické nespravedlnosti spáchané vưči nemuslimskému obyvatelstvu z jihu

\footnotetext{
30 Douglas [2003: 5].

31 Totten \& Markusen [2006: 70].

32 Douglas [2003: 7].

33 Deng [2010: 133].
} 
ukazují, že původ současných súdánských problémů se datuje ještě z doby před dědictvím nerovného koloniálního systému 20. století.

\section{Britská koloniální vláda a problém jižního Súdánu v období let 1889-1956}

Muslimské komunity severního Súdánu se v době mahdistického státu dělily na příznivce (následovníky) Mahdího (pod názvem Ansar) a na obyvatele východní části země, jimiž byli následovníci náboženské rodiny Mirghaniho, zakladatele islámské sekty nazývané Khatmiyya, kteří se stavěli proti mahdistickému státu a byli podporováni egyptskou vládou. Různé opoziční skupiny proti mahdistickému státu se nakonec spojily s anglo-egyptskými silami ve snaze odstranit mahdistický stát v bitvě u Omdurmanu 2. září 1898. Nová anglo-egyptská vláda označovaná za vládu kondominia pak spravovala jih a sever Súdánu odlišně. Tato anglo-egyptská (1898-1956) nová koloniální vláda se pro většinu obyvatel jihu nelišila od turecko-egyptské vlády (1820-1883) nebo od mahdistického státu (1883-1898), protože většinu příslušníků koloniální správy tvořily osoby, které sloužily již dvěma předchozím vládám. To se týkalo i začlenění malého počtu britských úředníkư; kromě toho byli do nové armády zařazeni súdánští vojáci, kteří sloužili v bývalé turecko-egyptské říši a svrženém mahdistickém státě. V prvních dvou desetiletích se jih z pohledu koloniální správy jevil jako zásobárna branců určených pro koloniální vojenské oddíly tvorrících v Súdánu stálou posádku. Tito vojáci pocházející z jihu zůstávali společensky separováni od Súdánců ze severu, a to díky jejich „otrockému“ původu. Jedinci z jihu nebyli nadšeni z toho, že se měli stát vojáky koloniální vlády, protože odvody byly i nadále násilné a do armády byli pravidelně zařazováni vězni a váleční zajatci. ${ }^{34}$

Politikou koloniální správy bylo od roku 1930 spravovat jižní Súdán nezávisle na severu, a to stejným zpo̊sobem, jakým byla spravována britská africká koloniální území, tedy jinak, než tomu bylo u arabských koloniálních území. ${ }^{35}$ Základní princip této „jižní politiky“ zveřejněný 25. ledna 1930 koloniální správou v Chartúmu spočíval v tom, že místní správa koloniálních národů by měla být uplatňována prostřednictvím domorodých struktur moci, měla by využívat domorodého práva a zvyků, a to v takové míře, jaká by odpovídala britské představě dobré vlády a spravedlnosti. ${ }^{36}$ Politickým cílem koloniální správy má být rozvoj jižního Súdánu, vzdělávání v angličtině, pomoc křestanským misionářům při šíření křest’anství a zamezení expanzi islámu do centrální Afriky vytvořením „početné křestanské populace, která by se případně spojila s Ugandou a vytvořila významný nárazník nebo překážku šíření víry, jakou je víra muslimská" ${ }^{37}$. Postoj britské koloniální vlády k jižnímu Súdánu se změnil po II. světové válce. Tlak ze strany egyptských a severo-súdánských nacionalistů totiž směřoval k nezávislosti sjednoceného Súdánu. K tomu, aby byl zahájen proces získání nezávislosti, byla na severu ustavena legislativní rada - první krok k národnímu parlamentu. Zásadní otázka, jak přimět jih ke sjednocení nezávislého Súdánu, byla vyřešena ze strany koloniální správy svoláním nereprezentativní konference v Jubě 12.-13. června 1947. Delegáti konference přitom nebyli vybráni lidmi z jihu, ale správcem. Účastníky této konference tak byly tři provinční vlády, včetně velitele policie,

\footnotetext{
34 Douglas [2003: 11].

35 Beshir [1968: 115].

36 Douglas [2003: 11].

37 Citováno Beshirem [1968: 39].
} 
několik kmenových náčelníků a několik velmi mladých správních úředníků. Konference, které předsedal státní tajemník, neměla ze strany obyvatel jihu mandát rozhodovat o takové významné otázce, jakou představovala jejich budoucnost. Účastníci konference se navíc navzájem neznali, pocházeli z různých provincií a neměli vzdělání na takové úrovni jako jádro nacionalistů ze severu. Předseda konference v diskusi nikdy nepřipustil, aby byla coby praktická alternativa uvedena možnost oddělené budoucí správy jihu. Závěrečné rozhodnutí konference přijaté vedoucími severosúdánských nacionalistů ovšem přesto znělo tak, že konference v Jubě vyřešila otázku jednoty Súdánu. Pravda o konferenci vyšla najevo až ve chvíli, kdy tatáž osoba, která konferenci předsedala, napsala o mnoho let později: „Na konferenci nemohla být přijata žádná rozhodnutí, protože její účastníci neměli žádný mandát od svého lidu [...] jediné rozhodnutí vycházející z konference jsem přijal já sám. “38

Z historického pohledu a na základě vztahu mezi severosúdánskými nacionalisty a jižními vůdci neexistovala úrodná půda pro vytvoření společného státu, ale z hlediska obyvatel jihu byli vůdci ze severu připraveni zaujmout místo Britů jako noví kolonizátoři. V př́pravě na získání nezávislosti vůdci z jihu zformovali novou politickou stranu - Liberální stranu (Liberal Party) a podíleli se na volbách do prvního samostatného parlamentu, konaných na konci června 1953. V novém parlamentu se zástupci Liberální strany pokusili nastolit otázku odděleného správního statutu pro jih, přičemž jako ústavní řešení navrhovali federální uspořádání. Tento požadavek byl ze strany severosúdánských nacionalistů ignorován a všechny nejvyšší pozice na jihu byly obsazeny úředníky ze severu; politicky nejaktivnější jižané v tom spatřovali začátek kolonizace jihu severem. ${ }^{39}$ Ve dnech 18.-21. ř́jna 1954 svolaly vznikající politické skupiny obyvatel jihu včetně členů Liberální strany, národnostních náčelníků ze všech tř́i jižních provincií a zástupců Súdánců z jihu v Chartúmu do Juby svou vlastní konferenci, aby na ní prodiskutovali politickou budoucnost Súdánu jako celku a politickou budoucnost jihu v rámci Súdánu. Bylo rozhodnuto hlasovat o nezávislosti Súdánu na Egyptu, ale za podmínky přijetí federálního systému v celé zemi s autonomním státem na jihu. Nebude-li toho dosaženo, jih si ponechá své právo na sebeurčení, jež zahrnovalo právo na úplnou nezávislost na severu. ${ }^{40}$ Požadavek svazového (spolkového) státu politických vůdců z jihu nebyl politickými vůdci ze severu respektován a 1. ledna 1956 byla vyhlášena nezávislost Súdánu v podobě jednotného, společného státu. ${ }^{41}$

\section{Vojenské povstání v jižním Súdánu a počátek první jihosúdánské občanské války (1955-1972)}

První všeobecné volby do samosprávného parlamentu v Súdánu se konaly v listopadu 1953 a v těchto volbách získala nejvyšší mandát - 51 z 97 míst v dolní komoře - Strana národní jednoty (National Union Party - NUP). Další strana ze severu nazvaná Umma získala 22 míst, jižní Liberální strana devět hlasů, Socialistická republikánská strana (Socialist Republican Party) a Protiimperialistická fronta (Anti-Imperialist Front - AIF) po jednom. Zbytek míst obsadili nezávislí, kteří se nicméně přikláněli $\mathrm{k}$ té či oné straně. Parlament

\footnotetext{
38 Robertson [1975: 107].

39 Douglas [2003: 27].

40 Zápis z konference v Jubě citovaný Douglasem [2003: 27].

41 Sidahmed [2007: 54].
} 
ovládaný politiky ze severu rozhodl, že politickou strukturou země bude unitární stát. Proces nahrazování státních úředníků z Británie súdánskými, tzv. súdanizace, obyvatele jihu ovšem zklamal, jak konstatoval bývalý ministr zahraničí Súdánu Francis Deng: „Spolu s neochabujícím vývojem směrem k nezávislému jednotnému Súdánu, jeden incident za druhým zesiloval obavy jihu z dominance severu. Postoj úředníků ze severu, diskreditující propaganda severních politických stran namířených jedna proti druhé v jejich boji o hlasy z jihu, nepř́telské strategie, jimiž se vláda snažila zahnat obyvatele jihu do pasivity, a především všechny zprávy o výsledcích súdánizace 800 míst obsazených předtím koloniálními velmocemi, z nichž jih získal pouze čtyři méně významné pozice, vehnala opozici na jihu do divoké revolty ze srpna 1955.“42 Nahrazení britských úředníků civilní správy a vojenských velitelů Súdánci ze severu vedlo k tomu, že v oblasti došlo ke vzpouře proti tomuto politickému ujařmení obyvatel z jihu těmi ze severu. Tato vzpoura vypukla nejprve u regimentu v distriktu Torit v Rovníkové provincii v srpnu 1955, celkem pak v tomto odbojném protestu přišlo o život 261 Súdánců ze severu a cca 75 jižanů. ${ }^{43}$ Súdánci z jihu považují vzpouru za počátek boje jižanů proti útlaku ze severu, podporovanému britskou koloniální vládou tím, že nepomohla obyvatelům z jihu vybudovat si svou vlastní budoucnost, ale pouze nutila severní politiky, aby ji nahradili. Násilné střety z 2. poloviny 20. století v jižním Súdánu tak byly důsledkem nespravedlivého přenosu moci z britské koloniální vlády na severosúdánské politiky. Po získání nezávislosti političtí představitelé jihu nepřestali doufat, že se podaří vybudovat federální demokratický stát Súdán a před volbami v roce 1957, následujícími po získání nezávislosti, se sjednotili do mnohem účinnějšího politického hnutí. Političtí aktivisté z jihu vytvořili Federální stranu (Federal Party), která se zúčastnila voleb v roce 1957, kde získala téměř všechna místa v parlamentu určená pro jih. Politici z jihu přivedli k politické aktivitě mladou generaci a církevní představitele a vytvořili jednotnou strategii s ostatními málo rozvinutými oblastmi na východě a na západě, čímž založili účinnou koalici s těmito regiony. Tlak na federalizaci ze strany jižního Súdánu nepřijala vládnoucí strana - Umma, a to je jedním z hlavních důvodů, proč došlo v roce $1958 \mathrm{k}$ předání moci armádě. ${ }^{44}$ Vojenská junta zakázala veškerou diskusi k otázce jižního Súdánu a vojenská vláda vedená generálem Abdu prosazovala politiku arabizace a islamizace jihu. Vyučovacím jazykem na školách se stala arabština, která nahradila angličtinu; z jihu byli vyhnáni křestanští misionáři a zejména mezi studenty byla propagována konverze $\mathrm{k}$ islámu. $\mathrm{V}$ arabizaci a islamizaci byl spatřován prostředek $\mathrm{k}$ dosažení národní jednoty, ovšem reakcí obyvatel jihu bylo vytvoření Jihosúdánské osvobozenecké fronty (Southern Sudan Liberation Front - SSLM), známější jako Anya-Nya, což je označení její vojenské složky.

Cílem hnutí bylo odtržení jihu a vytvoření nového nezávislého státu, ${ }^{45}$ vojenská vláda však odmítala uznat, že zde existuje „jižní problém“, a „nadále označovala za zdroj problému imperialisty a misionáře. Vojenská junta degradovala jižanské politiky v exilu na nastrčené loutky a agenty cizích mocností a misionáře v pevné víre, že jedinou cestou, jak dosáhnout integrace a jednoty, je za pomoci vojenské moci." ${ }^{6}$ Vojenská vláda

\footnotetext{
42 Deng [1973: 37].

43 Beshir [1968: 73].

44 Douglas [2003: 31].

45 Deng [1991: 25].

46 Beshir [1968: 86].
} 
byla nakonec svržena v roce 1964 lidovým povstáním, které Súdánci nazývají Říjnovou revolucí, následující civilní vláda ale zůstala u moci jen do roku 1969. Skupina vojáků, označující se za Svobodné důstojnické hnutí (Free Officers Movement), svrhla parlamentní režim a chopila se moci při vojenském převratu 25 . května $1969 .{ }^{47}$ Jeho vůdci ustavili Radu revolučního velení (Revolutionary Command Council - RCC) skládající se z 10 důstojníků pod vedením velitele převratu, plukovníka Džafaar Muhammad an-Nimajrí. Nimajrího vojenská vláda nejprve odstranila kř́idlo pravicových politiků a po červenci 1971, tj. po pokusu o další vojenský převrat, oslabila levicové politiky, především Komunistickou stranu Súdánu (Communist Party of Sudan - CPS); v průběhu konfliktu byli její čelní představitelé popraveni. Vojenský vưdce se dostal do čela súdánské politiky a zahájil tajné rozhovory s Osvobozeneckým hnutím jižního Súdánu (SSLM), jež vyvrcholily 27. února 1972 uzavřením dohody z Addis Abeby. Hlavním bodem této dohody je nastolení opatření vedoucích $\mathrm{k}$ dělbě moci mezi ústř̌ední vládou a jednotným jižním regionem s hlavním městem Juba a vlastním voleným shromážděním a radou ministrů. Co se jazykové politiky týče, zůstala arabština oficiálním jazykem a angličtina hlavním jazykem jižní oblasti. Byly podepsány i dodatky ke smlouvě týkající se opatření k zastavení palby a začlenění guerillových sil do národní armády. ${ }^{48}$

Únorová dohoda $\mathrm{z}$ Addis Abeby byla ratifikována a začleněna do regionálních vládních dokumentů v březnu 1972 a byla rovněž připojena k trvalé ústavě z roku 1973. Nicméně dohoda byla postupně oslabována ústřední vládou a nakonec zrušena 5. června 1982, kdy Nimajrí rozdělil jih na tři regiony. Stálá ústava z roku 1973 zřizovala Súdán coby sekulární stát se svobodou vyznání nejen pro křestany a Židy, ale i pro vyznavače tradičních náboženství. Sekulární zákony dále řešily vztahy mezi civilními občany a rovněž kriminální delikty; osobní či rodinné záležitosti postihovaly v případě muslimů zákon šaría a zvykové právo u velkého počtu venkovského obyvatelstva na severu i na jihu. Tato ústava byla zárukou pro všechna náboženství v zemi, ovšem Nimajrí, který v roce 1972 přinesl jihu mír, se nakonec stal symbolem války vzniklé kvưli ropě objevené v roce 1978. V záŕí 1983 pak prosadil aplikaci zákona šaría po celé zemi (později tento akt známe jako Zář́ijové zákony) a nedlouho poté rozpustil jihosúdánskou regionální vládu. Zrušení autonomie jižního regionu a zavedení islámských zákonů v celé zemi bylo ovlivněno př́znivými mezinárodními podmínkami pro súdánskou vojenskou vládu. V roce 1974 totiž došlo ke svržení Haile Selassieho, absolutistického monarchy panujícího v Etiopii padesát let a v roce 1977 nová vojenská vláda Etiopie uzavřela vojenskou základnu USA v zemi a vyhnala ze země americký vojenský personál. Ve stejném období podepsala etiopská vláda mírovou smlouvu na 20 let se Sovětským svazem a Súdán se tím pádem stal významným spojencem Spojených států jako regionální protiváha k Sověty podporované Etiopii. Objevení ropy v jižním Súdánu, které přilákalo americké naftařské společnosti, pak ještě zesílilo zájem Spojených států o súdánskou ekonomiku a spolu se zvolením republikánské vlády v USA v roce 1980 výrazně ovlivnilo roli Súdánu v mezinárodní politice. Nepřátelství Reaganovy administrativy vůči Libyi vedlo Spojené státy a Súdán k ještě užšímu vojenskému spojenectví; Súdán se stal součástí „Síly rychlého rozvoje“ („Rapid Development Force“), což dovolilo silám Spojených států provádět se súdánskou armádou společné vojenské

47 Daly [2007: 202].

48 The Addis Ababa Agreement on the problem of South Sudan [Wai 1973: 221-244]. 
manévry na súdánské půdě. „Nimajrí hrál s libyjskými a etiopskými kartami, aby si tak pojistil vojenské dodávky ze Spojených států. Spojené státy také zjistily, že ,obrana Súdánu‘ je užitečným nástrojem propagandy proti Libyi.“ 49

Nimajrí se dostal k moci v roce 1969, když uznal, že válka na jihu nemůže být vyřešena vojensky. Do roku 1983 byl přesvědčen, že má k dispozici dostatek moderních vojenských prostředků z USA, aby se mohl vyrovnat s jakoukoliv potenciální vojenskou revoltou v zemi. Reaganovu administrativu, která zásobovala súdánskou vládu, aby se mohla bránit vnějším nepřátelům, přitom nezajímalo, co Nimajrí dělá ve své vlastní zemi. Nimajrího vláda tak zrušila Dohodu z Addis Abeby a v lednu 1983 nařídila vojenskému praporu, který měl základnu na jihu, aby se přesunul na sever. Prapor byl stále pod velením bývalých guerillových bojovníků, začleněných do súdánské armády na základě Dohody z Addis Abeby a umístěných proto v jižním regionu. Dr. John Garang, tehdejší štábní velitel na vojenské škole v Omdurmanu, byl vyslán k praporu s úkolem vyjednávat. Ve skutečnosti však šlo o to, že Garang se již podílel na tajné dohodě mezi některými z důstojníků ve velení jižních oddílů, kteří měli v plánu přeběhnout s praporem do guerilly. Zrušení jižního regionu a útok na prapor, jenž se odmítl přesunout na sever, urychlily další vzpoury a dezerce z vojenské základny poblíž hranic s Etiopií; cca 2500 vojáků zběhlo k nové guerillové základně, jež byla vytvořena v Etiopii, a dalších 500 vojáků zůstalo na poli v Bahr-al Ghazal. Ti jen vytvořili posilu pro bojovníky, kteří odmítli přijmout dohodu z Addis Abeby a zůstali v buši. V červenci 1983 všechny tyto skupiny dezertérů vytvořily Súdánské lidové osvobozenecké hnutí (Sudan People’s Liberation Movement - SPLM) jakožto politickou organizaci a zformovaly jeho vojenské křídlo - Súdánskou lidovou osvobozeneckou armádu (Sudan People’s Liberation Army - SPLA) pod společným velitelem dr. Johnem Garangem. ${ }^{50}$ Zpočátku bylo cílem SPLM - podle slov samotného Johna Garanga pronesených v projevu 3. března 1984 - rozhodnout problém jihu, „který může být vyřešen pouze v kontextu jednotného Súdánu pod socialistickým systémem, který poskytne demokratická a lidská práva všem národnostem a zaručí svobodu všem náboženstvím, vírám a filozofickým názorům". ${ }^{1}$

Z tohoto projevu jasně vyplývá požadavek SPLM: vybudovat demokratickou společnost s rovnými právy pro všechna náboženství a s rovností všech národností v zemi, což vede nutně k závěru, že islám by neměl mít ve vztahu k ostatním náboženstvím zvláštní postavení. Z tohoto projevu můžeme dále vyvodit závěr, že SPLM odmítá pokusy řady súdánských vlád založit súdánskou národní identitu na arabštině, arabské kultuře a islámu. ${ }^{52}$ Počínaje vytvořením SPLM existovaly na budoucnost jižního Súdánu dva názory: jeden $\mathrm{z}$ nich byl definován vůdcem hnutí a druhý byl platformou starší organizace Jihosúdánského osvobozeneckého hnutí (South Sudan Liberation Movement - SSLM), jež preferovalo plnou nezávislost jižního Súdánu, avšak bylo potlačeno novým vedením. Vojenská konfrontace mezi SPLA a súdánskými vojenskými silami začala v květnu 1983 jejím cílem bylo ovládnout jižní Súdán. Lidové povstání zbavilo Nimajrího moci v dubnu 1985 a nahradilo ho jeho ministrem obrany; ten v roce 1986 vyhlásil parlamentní volby, které s sebou přinesly občanskou parlamentní správu vedenou stranickým vůdcem strany

\footnotetext{
49 Douglas [2003: 57].

50 Arop [2006: 74-75].

51 Garang [1992: 23].

52 Douglas [2003: 63].
} 
Umma Sadiqem al-Mahdim, jenž se stal premiérem. Předseda civilní vlády se v Addis Abebě setkal s vůdcem SPLM, aby spolu projednali vyřešení jihosúdánského konfliktu mírovou cestou. Sadiq al-Mahdi před volbami odsoudil užívání zákonů šaríya v celé zemi, ale poté, co se stal premiérem, odmítl tento zákon zrušit, a mírové řešení tak nepředstavovalo žádný pokrok; konečně v roce 1989 další vojenský puč vedený brigádním generálem Umarem al-Bašír svrhl občanskou vládu - převrat byl provázen nejhorším krveprolitím v dějinách nezávislého Súdánu. Z Bašírovy vojenské vlády se stalo arabsky zaměřené ideologické a fundamentalistické islámské hnutí se vzrůstajícím vztahem k panarabským a islamistickým hodnotám, hovoříme-li o válce spojované s nadějí na shromaždování podpory ze strany arabských zemí. Vláda využila své propagandistické mašinérie prohlášením, že válka o vyřešení jiho-súdánského konfliktu je válkou mezi Araby a Afrikou. Armáda slibovala, že „se nevzdá jediné pídě půdy této země“, a vládní činitelé spěchali do ciziny, aby žádali o prostředky k znovuzískání „arabských měst obsazených ,Afričany“ a ,nevěřícími““ ${ }^{53}$

Súdánská vláda podporovala opoziční osvobozenecké fronty v Etiopii během vlády Haile Selassieho a vojenské vlády Mengistu Haile Mariama. Etiopská vláda také od počátku až do svržení této vlády v květnu 1991 poskytovala SPLM veškerou materiální a diplomatickou podporu. Nová etiopská vláda ale vyhnala vůdce SPLM a uzavřela uprchlické tábory v Etiopii, v čemž súdánská vojenská vláda viděla př́iležitost oslabit a pokud možno zlikvidovat SPLM vojenskými prostředky. Jedna z výzev k islámské podpoře byla vydána rovněž Íránem. „Íránský prezident Alí Akbar Hášimí Rafsandžání navštívil v prosinci 1991 Chartúm, označil válku za $d z ̌ i h a ́ d$ a podepsal vojenské protokoly, včetně př́ílibu zaplatit 300 milionů dolarů za čínský vojenský materiál. “54 V 90. letech se politická atmosféra postupně obrátila proti vojenské vládě v Súdánu, a to $\mathrm{z}$ nejrůznějších důvodů, např́iklad kvůli podpoře Iráku během války v Perském zálivu, kvůli extrémnímu islamistickému programu, politice poskytování útočiště teroristům, včetně včetně Usámi bin Ládina, který v Súdánu žil v letech 1992-1996, a kvůli podpoře extremistických islamistických skupin v muslimském světě. Kritický bod obratu pro súdánskou vládu nastal v červnu 1995 při pokusu o zavraždění egyptského prezidenta Husni Mubaraka v Addis Abebě, kdy etiopská vláda obvinila Súdán z poskytnutí logistické podpory a útočiště pachatelům atentátu. V květnu 1996 uvalila Rada bezpečnosti OSN na Súdán neekonomické sankce a americká vláda zařadila Súdán na svůj seznam států sponzorujících terorismus a uvalila na něj jednostranné sankce. První krok k uznání práva na sebeurčení jižního Súdánu učinila Národní demokratická aliance (National Democratic Alliance - NDA) založená v roce 1989; skládá se z ozbrojených i neozbrojených severních a jižních organizací, profesionálních asociací, odborových svazů a SPLA. V roce 1995 Národní demokratická aliance vydala deklaraci z Asmary, která zdůraznila nutnost založit budoucí politický systém na multietnické, multináboženské a multirasové společnosti a potvrdila právo jihu na sebeurčení.

Regionální vládní organizace Afrického rohu nazvaná Mezivládní úřad pro rozvoj (Inter-governmental Authority on Development - IGAD) je nejdéle existující mírová iniciativa v Súdánu. Svou činnost zahájila v roce 1993 a předsedá jí Keňa. IGAD v roce 1994 vyhlásil Deklaraci zásad, soubor krátkých tezí, které tvořily a tvoří rámec následných jednání. Deklarace zásad předvídá mírovou dohodu uspořádanou kolem demokratického

53 International Crisis Group [2002: 15].

54 International Crisis Group [2002: 16]. 
a sekulárního Súdánu a požaduje podíl na národním bohatství a zdrojích. Pokud by se to nepodařilo, považuje za nezbytné jednání o modalitách v meziobdobí následovaném referendem o sebeurčení jihu. Po mnoha letech váhání přijala súdánská vláda Deklaraci zásad jako základ pro jednání v roce 1997. Africký roh je přesto dál regionem, kde dochází k řadě různých zuřivých konfliktů; v roce 1998 tř̌i hlavní země podporující SPLM (Etiopie, Eritrea a Uganda) vstoupily do devastujících válek. Etiopie a Eritrea vstoupily do války kvưli společným hranicím, zatímco Uganda se dostala do konfliktu s Demokratickou republikou Kongo, což oslabilo úsilí IGAD .

Mírová iniciativa Spojených států koordinovaná s IGAD přinesla v roce 2002 alespoň určité vyjasnění situace. Dne 20. července 2002 byl podepsán protokol mezi SPLM a súdánskou vládou, který řešil otázku sebeurčení, státu a náboženství. V tomto protokolu bylo potvrzeno právo zvolit si nezávislost, načež Po třech letech dlouhých diskusí byla v lednu 2005 podepsána súdánskou vládou a SPLM Dohoda o úplném míru v Súdánu (Sudan's Comprehensive Peace Agreement - CPA), která ukončila 21 let války mezi jižním Súdánem a súdánskou vládou. Klíčovými body této dohody jsou následující teze:

1. Uznání práva jižního Súdánu na sebeurčení. ${ }^{55}$

2. Odluka státu a náboženství tím, že budou povoleny odchylky právních systémů, aby se tak vyšlo vstř́íc islámské (šaría) a křest̉anské (sekulární) tradici. ${ }^{56}$

3. Dohoda o úplném míru vytvořila podmínky pro mezinárodně monitorované referendum v roce 2011, v němž byly obyvatelům jižního Súdánu nabídnuty dvě možnosti: pokračující jednota se severem, nebo oddělení za účelem plné nezávislosti.

CPA potvrdila $v$ přechodném období mezi červencem 2005 a rokem 2011 podíl na vládě na národní úrovni a autonomní vládu pro jižní Súdán s jeho ozbrojenými silami. Dohoda o podílu na přírodních zdrojích umožnila jižanské vládě přístup k cenným zdrojům ropy, která představuje hlavní produkt jihosúdánského regionu. Na základě dohody CPA došlo k novému politickému uspořádání, včetně rozdělení moci mezi vládnoucí Stranou národního kongresu (National Congress Party - NCP) a Súdánským lidově osvobozeneckým hnutím (Sudan People’s Liberation Movement - SPLM). Byla vytvořena Vláda národní jednoty (Government of National Unity), v níž NCP má $52 \%$ a SPLM $28 \%$, přičemž podobné rozložení míst v národním shromáždění bylo určeno pro období do parlamentních voleb, které byly naplánovány na rok 2009, ale byly realizovány až v roce 2010 . Dohoda určila, že prezident al-Bašír zůstane ve funkci a předseda SPLM bude jeho prvním viceprezidentem.

CPA rovněž vytvořila autonomní Vládu jižního Súdánu (Government of Southern Sudan - GOSS) s nezávislou exekutivou, legislativou a soudnictvím. ${ }^{57}$ Hlavním městem jižního Súdánu se stala Juba, kde sídlí i GOSS (v níž převažují příslušníci SPLM). GOSS má široké pravomoci v řadě oblastí vyjma těch, které jsou obvykle spojeny s národní suverenitou, jako je národní bezpečnost, směřování zahraniční politiky atd. $Z$ bezpečnostního hlediska je v dohodě určeno, že SPLM zajistí své vlastní vojenské síly, aby tak v přechodném období zůstala oddělena od súdánských ozbrojených sil. Abychom uzavřeli tuto část

\footnotetext{
55 Comprehensive Peace Agreement(CPA) between The Government of The Republic of The Sudan and The Sudan People's Liberation Movement/Sudan People's Liberation Army. [2005: Part A: Agreed Principles 1.3].

56 Healy [2008: 29].

57 Comprehensive Peace Agreement(CPA) between The Government of The Republic of The Sudan and The Sudan People's Liberation Movement/Sudan People's Liberation Army [2005].
} 
článku, rádi bychom uvedli cenu, kterou obyvatelé jižního Súdánu za dlouhodobý konflikt zaplatili, a také jejich výhledy do budoucna.

„Odhaduje se, že v důsledku bojů během uplynulých 18 let zahynuly dva miliony lidí, jako oběti př́mého násilí nebo následkem vyhladovění a nemocí. Půl milionu uprchlíků se rozptýlilo do sousedních zemí a odhadem čtyři miliony lidí byly vyhnány a přemístěny ze svých domovů v rámci Súdánu - jedná se o největší podobné přemístění na světě v současné době. Ve skutečnosti jeden z každých osmi lidí zbavených domova díky válce a rozptýlených po světě pochází ze Súdánu. "58 Po všem tomto utrpení, které je důsledkem jejich odmítnutí začlenit se do súdánského státu, ${ }^{59}$ konečně nazrál čas, kdy se vyhnanců někdo zeptá, zda chtějí tvořit část státu, jenž je uvrhl do té nejhorší války, která kdy v dějinách Afriky probíhala. Podle Národního demokratického institutu směřují obyvatelé jižního Súdánu k plné nezávislosti a také podle hlasování uskutečněného v rámci výzkumu v dubnu 2006 lidé vyjádřili „téměř úplnou podporu nezávislosti.“" ${ }^{60}$ Doufáme, že zájem lidu bude respektován a že v tomto nestabilním regionu Afriky začne konečně vát mírový vítr.

\section{Politický konflikt v současném Somálsku}

Somálsko otevřelo novou kapitolu v dějinách současného státu, když v lednu 1991 přestala existovat ústřední vláda poté, co ozbrojené opoziční skupiny vyhnaly diktátorskou vládu prezidenta Siyad Barreho. Tyto opoziční síly, schopné odstranit starý režim, ale nenalezly společný jazyk k vybudování nové ústřední vlády, jež by zemi spravovala pod jednou vládou. Neshoda v názoru na to, jakým způsobem vytvořit ústřední vládu Somálska, vedla následně k rozdrobení země na tři regiony. ${ }^{61}$ Bývalé Britské Somálsko (British Somaliland), které získalo nezávislost na Velké Británii 26. června 1960, spolu s Italským Somálskem vytvořily 1. července 1960 Somálskou republiku, přičemž Somálská republika existovala jako nezávislý stát od roku 1960 do roku 1991. Republika Somaliland vyhlásila 18. května 1991 svou nezávislost na již neexistujícím somálském státu ${ }^{62}$ a severovýchodní část země rovněž deklarovala v roce 1998 svou autonomii pod jménem Puntland. Mogadišo a další jižní část Somálska, rozdělená mezi různé válečníky, se následně ponořila do chaosu. Ani mírová mise Spojených národů vyslaná do Somálska a vedená Spojenými státy pod heslem „Operace k znovunastolení naděje“ (Operation Restore Hope) v letech 1992-1995 nedokázala v Somálsku obnovit mír a vytvořit vládu, byla ze Somálska vypuzena a zanechala $v$ zemi chaos. ${ }^{63} \mathrm{O}$ vytvoření ústřední vlády dále proběhla mezi somálským frakčními skupinami řada jednání a došlo k mnoha mírovým dohodám o vytvoření ústřední vlády, vedeným spojeným úsilím Spojených národů, Evropské unie, Africké unie, Arabské ligy a Mezivládním úřadem pro rozvoj (IGAD), až do současné doby však žádná úspěšná vláda nevznikla. Posledním pokusem bylo po dvou letech vyjednávání mezi různými somálskými organizacemi na konci roku 2004 zř́zení Přechodné federální vlády (Transitional Federal Government - TFG) v Keni, jejímž sídlem se po dobu dvou let stalo

\footnotetext{
58 International Crisis Group [2002: 3].

59 Chabal [2009: 99].

60 Prendergast \& Thomas-Fensen [2007: 72].

61 Lewis [2002: 263].

62 International Crisis Group [2003: 6]

63 Menkhaus [2004: 8].
} 
malé městečko Baidoa, aniž by ale její představitelé ovládali nějaké území, načež se na konci roku 2006 za masívní vojenské podpory ze strany Etiopie přestěhovala do Mogadiša. ${ }^{64}$ Přechodná federální vláda Somálska čelila silnému odporu ze strany Unie islámských soudních dvorů (Union of Islamic courts), jež ovládala většinu jižního Somálska od druhé poloviny roku 2006. TFG, vedená 40000 příslušníky silné etiopské armády, byla schopna porazit Unii v konvenční válce. Nyní se Unie islámských soudních dvorů přeskupila tak, aby s vládou v Mogadišu bojovala formou guerrillové války. Cílem této části příspěvku je analyzovat vnitřní a vnější prríčiny konce vlády Siyada Barreho, regionální vliv různých politických skupin v Somálsku, které stály v cestě vytvoření ústřední vlády v zemi, a různé scénáře perspektivy vytvoření ústřední vlády v budoucnosti.

\section{První demokratická vláda Somálců po získání nezávislosti}

Území somálského národa bylo rozděleno v průběhu kolonizace této části Afriky do pěti koloniálních území: Francouzské Somálsko, Britské Somálsko, Italské Somálsko, Ogaden přičleněný $\mathrm{k}$ Etiopskému císařství a další část území připojená k Severovýchodní Keni. ${ }^{65}$ Republika Somálsko byla vytvořena 1. července 1960 z Unie Britského a Italského Somálska vedeného Somálskou ligou mládeže (Somali Youth League). ${ }^{66} \mathrm{~V}$ průběhu založení Somálské republiky do ní nebyly začleněny tři části území (Francouzské Somálsko, Ogaden pod etiopskou císařskou vládou a somálské území v Severovýchodní Keni), protože koloniální páni těchto území nebyli ochotni dovolit Somálcům, aby si určili svou politickou budoucnost. ${ }^{67}$ Otázka, jak začlenit do republiky tato tři zbývající teritoria, se stala základním problémem obou předchozích vlád - civilní i vojenské. Nová republika byla svazkem dvou koloniálních území s rozdílným koloniálním, politickým a správním dědictvím. Jedním z prvních problémů, daných jejich dvojím koloniálním dědictvím, jemuž museli čelit vưdci nové republiky, byli úředníci, kteří byli vyškoleni a pracovali v rámci britského a italského správního systému, ${ }^{68}$ tyto systémy se co do administrativy totiž radikálně lišily. Nová republika je zařadila do jednotného mzdového systému, což platilo pro všechny úředníky ve všech vládních odvětvích, včetně národní policie a armády.

Rozdíly ovšem nespočívaly jen v problémech pramenících ze dvou právních systémů. Severní právní systém byl založen primárně na anglickém obecném a statutárním právu (English Common and Stature Law) a Indickém trestním kodexu (Indian Penal Code) a na jihu systém závisel hlavně na italském koloniálním zákoníku. ${ }^{69}$ Ve finančních a účetních postupech byla situace podobně složitá vzhledem k velkým rozdílům v přístupu používaném britským systémem na severu a italským na jihu; významně se na severu a na jihu lišily také tarify, cla a obchodní vzorce. Všechny tyto problémy nebyly vyřešeny před vyhlášením nezávislosti, ale staly se dvojím dědictvím republiky. Zmíněné rozdíly byly dále prohlubovány i lingvistickými bariérami, které - podobně jako italská vyučovací

\footnotetext{
${ }^{64}$ Human Rights Watch [December 2008: 3, 1-56432-415-x].

65 Drysdale [1964: 8-9].

66 Touval [1963: 112].

67 Abdi [2007: 17-30].

68 Itálie, ač ve druhé světové válce poražená, získala nad územím bývalého Italského Somálska poručenský mandát, který vykonávala až do roku 1960.

69 Lewis [2002: 170].
} 
tradice na jižních školách a britská na severních - ovlivňovaly veškeré oblasti činnosti, soukromé stejně tak jako veřejné. Také problém infrastruktury spojující sever s hlavním městem a nedostatek odborníků nezbytných pro překlad $\mathrm{z}$ italštiny a angličtiny stály v cestě integraci obou regionů.

Sever a jih měly rovněž odlišný názor na novou prozatímní ústavu, o čemž svědčily výsledky národního referenda, které se konalo rok po získání nezávislosti, konkrétně 20. června 1961. Sever ústavu neschválil, více než $60 \%$ hlasujících se postavilo proti ní, v hlavním městě Hargeysa to bylo $72 \%$, v jiných městech jako Berbera procentuální poměr hlasů proti ústavě tvořil $66 \%$, v Burco a v Ceerigaabu $69 \%$. Na jihu bylo naopak zaznamenáno více než milion a půl hlasů ve prospěch ústavy. ${ }^{70}$

Nesouhlas na severu vyjádřili také vojáci; pramenil mj. z vojenského převratu z prosince 1961, jenž neměl dlouhého trvání. Revoltu vedla skupina důstojníků vyškolených ve Velké Británii, kteří po získání nezávislosti sloužili pod italskými velícími důstojníky dosazenými na sever. Vedeni směsicí osobních ambicí a severního patriotismu tito britsky vychovaní nižší důstojníci v tichosti uvěznili své nadřízené z jihu, na něž hleděli jako na nespravedlivě dosazené. Konečným cílem tohoto puče bylo oddělit se od jihu a zničit republiku. ${ }^{71}$ Pro mnoho místních lidí to bylo příliš; jejich spontánně zorganizované jednotky vzpouru potlačily a odbojní důstojníci byli vsazeni do vězení, takže ve chvíli, kdy z Mogadiša dorazily vládní posily a policie, byla už celá záležitost uzavřena. Vůdci byli uvězněni a postaveni před soud o rok později, řada důstojníků byla propuštěna nebo jim byla snížena hodnost, zatímco těm, kteří zůstali loajální, se dostalo odměny. Zároveň bylo vyvinuto nové úsilí ve snaze dosáhnout plnější integrace obou regionů, nový služební zákon, který sjednocoval mzdy a služební podmínky v republice jako celku, byl ratifikován v bř̀znu 1962.

Hlavním problémem vedení Somálské republiky od vzniku tohoto státu do současnosti zůstává, jak se spojit se třemi teritorii, která jsou součástí cizích států, jmenovitě s Francouzským Somálskem - Džibutskem, Haudem a Ogadenem v jihovýchodní Etiopii a severním pohraničním distriktem v Keni. Situaci, jíž čelila v roce 1960 nově vzniklá republika, nejlépe popisují slova předsedy vlády. Abd ar Rashid napsal o problémech republiky: „Naším neštěstím je, že sousedící země, s nimiž se - jako se zbytkem Afriky snažíme navázat konstruktivní a harmonické vztahy, nejsou našimi sousedy. Našimi sousedy jsou naši somálští př́buzní, jejichž občanství bylo zfalšováno nevybíravými úpravami hranic. Musejí překračovat umělé hranice, aby měli přístup na své pastviny. Obývají stejné území a věnují se pastevectví stejně jako my. Mluvíme stejným jazykem. Máme společnou víru, společnou kulturu a tytéž tradice. Jak se můžeme dívat na své bratry jako na cizince? Samozřejmě že máme silnou a velmi přirozenou touhu být sjednoceni. "První krok k vyřešení této situace byl podniknut v roce 1960, kdy byl protektorát Somaliland (bývalé Italské Somálsko) připojen k Somálsku. Tento akt nebyl aktem „kolonialismu“, „expanzionismu“ či „anexe“, nýbrž pozitivním příspěvkem k míru a jednotě v Africe. ${ }^{72}$ Právě to je jádrem pansomalismu, v jehož rámci se většina somálských politických vůdců od získání nezávislosti až dodnes snaží sjednotit všechna území obývaná Somálci v jednom státě.

\footnotetext{
70 Bulhan [1999: 14].

71 Lewis [2002: 173-174].

72 Abd ar-Rashid (1962: vi), citován Lewisem [2002: 179].
} 


\section{Období vojenské vlády}

Somálsko bylo demokratickou zemí od získání nezávislosti v roce 1960 až do 15. ř́ijna 1969, kdy v důsledku vojenského převratu uskutečněného somálskou armádou došlo $\mathrm{k}$ převzetí politické moci a odstranění parlamentního systému v zemi. Vůdci vojenského puče pozastavili působnost ústavy, zrušili Nejvyšší soud, uzavřeli Národní shromáždění, vyhlásili, že veškeré politické strany jsou ilegální, a vládu svěřili do rukou Vrchní revoluční rady, kterou zřídili. Nový režim kladl důraz na potlačení korupce a kmenového nepotismu a na znovunastolení spravedlivé a čestné společnosti, v níž bude patřičná pozornost věnována skutečnému zlepšení ekonomické a společenské situace pro všechny. ${ }^{73}$

Co se zahraniční politiky týče, prohlásila vojenská vláda, že existující smlouvy budou uznány a boj za sjednocení Somálců bude pokračovat, zatímco další podpora bude poskytnuta obecně osvobozeneckým hnutím a boji proti kolonialismu. Název státu se změnil ze Somálské republiky (Republic of Somalia) na Demokratickou somálskou republiku (Democratic Republic of Somalia). Vůdci vojenského převratu vyhlásili vytvoření Vrchní revoluční rady (Supreme Revolutionary Council) vedené generálem Muhammadem Siyadem Barre (6. 10. 1919 - 2. 1. 1995), který byl vojenským velitelem od roku 1965. U př́ležitosti prvního výročí puče, tj. 21. ř́jna 1970, prohlásil předseda vojenské vlády generál Siyad Barre, že Somálsko se od této chvíle bude řídit ideologií vědeckého socialismu. ${ }^{74}$ V̌̌decký socialismus (v somálském pojetí „dělba bohatství/majetku založená na moudrosti“) se nyní stal úhelným kamenem oficiální politiky a úzce se spojil s myšlenkami jednoty nebo „soudržnosti/semknutosti“, spoléhání sama na sebe a svépomoci. Vyhlášení příchodu vědeckého socialismu se pojilo s důrazným odsouzením klanismu; pregnantně tento přístup vyjadřovalo oficiální heslo „klanismus rozděloval (tam, kde) socialismus spojuje“ ${ }^{75}$

Národní kampaň neboli „prioritní program“ namířený proti klanismu vyvrcholil demonstracemi koncem roku 1970 a na počátku roku 1971, kdy obrazy představující „klanismus, korupci, nepotismus a anarchii“ byly symbolicky páleny či pochovávány v hlavních centrech republiky. Mezi nejambicióznější a nejlépe viditelné rozvojové programy Vrchní revoluční rady patřily kampaně proti negramotnosti ve městech a na venkově z let 1973 a 1975. V roce 1972 přijala vláda generála Siyada Barreho odvážné a rozumné rozhodnutí přijmout latinskou abecedu coby oficiální písmo pro národní jazyk - somálštinu. Rozhodnutí užívat latinku k přepisu národního jazyka se ukázalo jako populární a kampaň proti negramotnosti ve městech z roku 1973 byla velmi úspěšná. ${ }^{76}$

Zkušenosti z ostatních socialistických zemí přivedly vojenskou vládu Siyada Barre $\mathrm{k}$ tomu, že pro zavedení vědeckého socialismu bude potřeba socialistická strana; aby byl tento vzorec naplněn, bylo v červenci 1976 vyhlášeno založení Somálské socialistické revoluční strany (Somali Socialist Revolutionary Party) a vojenská vláda byla oficiálně nahrazena vládou lidovou - na tento vývoj již dlouhou dobu naléhali Rusové. Stranická struktura se dále rozvíjela velmi podobně jako stranický systém v SSSR.

\footnotetext{
73 Ahmed \& Green [1999: 116-17].

74 Patron [1980: 502].

75 Lewis [2002: 209].

76 Adam [1983: 33].
} 


\section{Etiopsko-somálská válka v Ogadenu v letech 1977-78 a začátek konce vlády Siyada Barreho}

Ogaden je část území obývaná somálským národem, včleněná do říšského (imperiálního) území Etiopie v roce 1886, kdy Menelik II. kolonizoval (vybaven zbraněmi poskytnutými Francií, Itálií a carským Ruskem) tuto část Afrického rohu. ${ }^{77}$ Toto rozšíření etiopské nadvlády, časově shodné s dělbou somálského pobřeží mezi Francii, Británii a Itálii, vyvolalo zuřivý zápas dervišů, kteří pod vedením nacionalistického ogadenského šejka Muhammeda Abdille Hassana bojovali v letech 1900-192078 za získání nezávislosti Somálců na cizí nadvládě. Etiopská revoluce z roku 1974 zničila půl století trvající absolutní monarchii Haile Selassieho, ${ }^{79}$ přičemž vláda Siyada Barreho se domnívala, že za nové etiopské vlády se podaří spojit Ogaden se Somálskem - at' už vyjednáváním, nebo prostřednictvím síly. Ogadenští nacionalisté, organizovaní pod vlajkou Západosomálské osvobozenecké fronty (Western Somali Liberation Front - WSLF), následně zahájili v roce 1976 osvobozeneckou válku proti etiopské koloniální moci. Zhruba v téže době generál Siyad Barre vyslal do Addis Abeby emisary, kteří se měli pokusit vyjednávat ve věci Ogadenu s novými vojenskými vůdci, obě revoluční vlády ale nebyly schopny se v této záležitosti dohodnout.

$\mathrm{V}$ téže době se rovněž významně zhoršily vztahy mezi USA a novou etiopskou vojenskou vládou. Americká vláda zastavila vojenskou pomoc Etiopii z důvodu porušování lidských práv, a to zejména poté, co nová vláda zmasakrovala 59 bývalých ministrů Haile Selassieho a dalších vrcholných vládních představitelů. ${ }^{80} \mathrm{~V}$ dubnu 1977 na to Mengistův režim odpověděl uzavřením americké vojenské spojovací základny v Asmaře a vypovězením amerických vojenských poradců ze země. ${ }^{81}$ V květnu téhož roku pak navštívil Mengistu Moskvu a výsledkem návštěvy byla dohoda o vojenské spolupráci se Sovětským svazem. V této době se Etiopie stala zemí vedenou zásadami vědeckého socialismu stejně jako její jihovýchodní soused Somálsko. Generál Siyad Barre odjel do Moskvy koncem srpna, aby zde požádal o vojenskou a diplomatickou podporu ze strany Sovětského svazu ve válce proti Etiopii. Sovětský svaz žádost Somálska odmítl a svou podporu věnoval Etiopii, kterou zásoboval letadly, tanky a těžkými zbraněmi. Somálská vláda rozezlená postojem Moskvy, jenž byl v rozporu se vzájemnou vojenskou dohodou, vypověděla ze země 6000 sovětských vojenských a civilních zaměstnanců s rodinami, a to během jediného týdne. Ve stejném období somálské pozemní síly za podpory leteckých sil okupovaly jménem Západosomálské osvobozenecké fronty velkou část území jihovýchodní Etiopie, o níž prohlašovaly, že patřila Somálcům ještě před etiopským záborem na konci 19. století. Vojenská prríprava v Etiopii byla v období deštů roku 1977 na vysoké úrovni: cca 70000 rolníků vyškolených Kubánci a vyzbrojených Rusy pochodovalo 26. června ulicemi Addis Abeby. ${ }^{82}$ Pod heslem „V̌̌ichni na východní válečnou frontu“ zahájila etiopská armáda a milice za podpory Rusů a Kubánců v únoru 1978 protiútoky na somálské pozice kolem středověkého města Hararu, Diredawy a Jidjigy. Somálská vláda následně oznámila 9. března stažení svých sil

\footnotetext{
77 Gaddaa [1980: 46], Abdi [2007].

78 Castagno [1964: 542], Záhořík [2009: 41].

79 Clapham [1988: 42-43].

80 Tareke [2009: 40].

81 Henze [2001: 298-99].

82 Lewis [2002: 233].
} 
z etiopského území v důsledku vojenské porážky a tlaku vyvíjeného západními zeměmi na respektování územní integrity Etiopie.

I když válka o Ogaden prozatím skončila vítězstvím Etiopie, politika Somálska podporovat Západosomálskou osvobozeneckou frontu pokračovala i nadále. Ponižující porážka Somálska v Ogadenu vedla 9. dubna 1978 k pokusu o převrat provedený vojáky z kasáren na jihu; v boji se silami loajálními k prezidentu Siyad Barremu, který vyvázl nezraněn, údajně zemřelo pět set vzbouřených vojáků. Někteří z vůdců - plukovníci z klanu Majerteynů - uprchli do Keni. Vůdci pokusu o převrat z roku 1978, převážně prŕíslušníci klanů Mudugh a Majerteyn, založili koncem roku 1981 Somálskou demokratickou frontu spásy (Somali Salvation Democratic Front - SSDF), guerillovou organizaci podporovanou Etiopií. V téže době byla v roce 1981 založena ve Velké Británii opoziční druhá politická organizace, Somálské národní hnutí (Somali National Movement - SNM), které bylo podporováno především klany Isaq ze severního regionu. ${ }^{83}$ SNM zahájilo svou činnost v Londýně a v Etiopii a vyhlásilo, že své úsilí bude koordinovat se SSDF. Obě politické organizace přitom nacházely podporu v různých klanech. Hnutí SSDF odráželo do jisté míry aroganci příslušníků klanu Majerteyn, jehož politické aspirace byly zatlačeny do pozadí mocí Marehanů Siyada Barreho; SNM tlumočilo stížnosti Isaqů ze severu vycházející z neadekvátní politické reprezentace.

Obchod s hospodářskými zvířaty, v němž obchodníci klanu Isaq sehrávali klíčovou roli, utrpěl vážnou ránu v roce 1983, kdy saúdská vláda uvalila v důsledku dobytčího moru embargo na dovoz hospodářských zvírat ze Somálska. V témže roce zakázala somálská vláda prodej a pěstování stimulující narkotické rostliny qat (catha edulis), která byla v severovýchodních regionech výnosným prodejním artiklem. Tento krok byl na severu interpretován jako další útok na podnikatelské a obchodní aktivity Isaqů. K těmto problémům navíc přistupoval velký počet utečenců na severu; vzrůstající odpor k přímé vojenské vládě z Mogadiša konflikt na severu dále jitřil. Řada prominentů ze severu byla uvězněna na základě podezření, že podporují Somálské národní hnutí. Za těchto okolností mohlo SNM počítat se značnou podporou veřejnosti a zahájilo řadu úspěšných vojenských operací včetně spektakulárního osvobození vězňů z vězení Mandera v lednu 1983; v roce 1986 byl zavražděn šéf Národní bezpečnostní služby v severních regionech.

Válka proti nejrůznějším národnostním hnutím $\mathrm{v}$ různých částech země přinutila Mengistovu vládu v Etiopii hledat dočasné řešení konfliktu se Somálskem. Pokud by Etiopie dosáhla jisté mírové dohody se Somálskem, mohla by přesunout velký počet vojenských jednotek ze somálské hranice do jiných částí země, aby tak mohly bojovat s ostatními osvobozeneckými frontami. Jednání mezi oběma zeměmi přineslo své ovoce - hlavy obou zemí podepsaly v dubnu 1988 na neutrálním území v Džibuti mírovou smlouvu, jež zavazovala obě strany $\mathrm{k}$ ukončení podpory skupinám bojujícím proti druhému státu. ${ }^{84}$ Tento krok může být považován za konečný podnět k vypuknutí krutých válek, které spolu se všeobecným zhroucením vládních institucí a ekonomiky - velmi efektivně zničily Somálsko ještě dávno předtím, než došlo v lednu 1991 ke skutečnému svržení a ostudnému vyhnání Siyad Bareho s jeho osobní gardou z válkou poznamenaného města silou Jednotného somálského kongresu (United Somali Congress - USC, založen v Rímě v roce

83 Prunier [1995: 5].

${ }^{84}$ Lewis [2002: 162]. 
1989), složeného z příslušníků klanů Hawiye a vedeného generálem Muhammadem Farah „Aideedem“. 85 V době Siyadova útěku do Nigérie se Somálsko rozpadlo do tradičních klanových a rodových částí, které - při absenci jiných forem zákona a pořádku - jako jediné nabízely určitý stupeň bezpečí. Když vyhnali z Mogadiša zbité síly Siyada Barreho, nedokázali se hawijští vůdci Spojeného somálského kongresu (generál Muhammed Farah Aideed, který měl úzké vztahy s Isaqským národním hnutím, a Ali Mahdi - prominentní obchodník z Mogadiša, jenž již dříve velmi významně podporoval kongres finančně) shodnout na tom, jak se podělí o moc. Spojený somálský kongres se rozdělil na dvě skupiny pod vedením generála Aideeda a Ali Mahdiho, přičemž nesoulad mezi oběma vůdci v otázce vytvoření ústřední vládu v Mogadišu rozdělil město na severní a jižní část ovládané dvěma hawijskými subklany; Ali Mahdi byl podporován svým subklanem Abgal a generál Muhammad Farah Aideed subklanem Habar Gidir, a rozpoutal městskou válku, načež se rozpoutal nekonečný konflikt. Divoké boje se rozšírily i mimo Mogadišo a přinesly s sebou devastaci a hladomor na většině území jižního Somálska.

Těmi, kdo za této situace trpěli nejvíc, byli ti nejmírumilovnější, tedy místní zemědělci Dir Mirifleh (Rahanwehn), jimž v bojích chyběl lidský potenciál i výzbroj a kteří byli nuceni opustit svá pole a uprchnout před divokými nájezdy potulných milic. Na severovýchodě se poté, kdy byla tato oblast osvobozena Majerteynskou somálskou demokratickou frontou spásy (Somali Salvation Democratic Front - SSDF) pod vedením plukovníka Abdillahi Yusufa, tato na klanové př́slušnosti založená organizace spojila s tradičními klanovými staršími a začala postupně budovat místní správu.

\section{Vyhlášení nezávislosti Republiky Somaliland}

Republika Somaliland, území obývané 3.5 miliony obyvatel vedených Somálským národním hnutím (SNM), vyhlásila svou nezávislost na Somálsku 18. května 1991. Aby potvrdila svou identitu, vrátila se Republika Somaliland ke svému statutu z vyhlášení nezávislosti 26. června 1960 a revokovala svoje spojení s bývalým Italským Somálskem, k němuž došlo 1. července 1960. ${ }^{86}$ Po uplynutí přechodného období 1991-1993 se v Boramě konala v květnu 1993 velká historická konference, která přijala přechodnou národní chartu a jmenovala Muhammada Haji Ibrahima Igala (15. 7. 1928 - 3. 5. 2002) prezidentem. Boramská konference tak položila základy budoucnosti země a jejím výsledkem byla Mírová charta s cílem posílit bezpečnost a upravit roli tradičních místních starších ve všech aspektech mírového úsilí. Konference rovněž formulovala již zmíněnou národní chartu, která měla po dva roky sloužit jako dočasná ústava země; nová vláda Muhammada Haji Ibrahima Igala dostala za úkol navrhnout formální ústavu a dovést zemi k referendu o této ústavě. Nejskvělejším rysem tohoto procesu byla podnětná inovace ve formě dvoukomorového parlamentního systému s nevolenou horní komorou, složenou z tradičních starších, a s volenou dolní komorou reprezentantů: jedná se o svého druhu kompromis mezi starým SNM založeným na klanové př́íslušnosti a potřebami moderní správy. V současné době má Somaliland novou ústavu s voleným parlamentem a podle mezinárodních pozorovatelů je to relativně nejdemokratičtější země regionu Afrického rohu.

85 Prunier [1995: 6].

${ }^{86}$ Africa Report No 66 [International Crisis Group 2002]. 


\section{Jižní Somálsko a jeho konflikty}

Somálsko se prakticky rozdělilo na tři autonomní regiony; Republika Somaliland vyhlásila svou nezávislost v roce 1991, severovýchodní část země vyhlásila autonomii pod jménem Puntland. Nyní se soustředíme na zbývající jižní region jižního Somálska včetně Mogadiša. Vnitřní konflikt v rámci Svazu somálského kongresu (Union of Somali Congress - USC) týkající se otázky, kdo bude tvořit vládu, rozdělil město na dvě polarizované frakce generála Muhammada Faraha Aideeda a Ali Mahdiho. Konflikt mezi oběma frakcemi vedl k válce, v níž přišlo o život velké množství lidí. Spojené národy se snažily zachránit životy lidí trpících hladomorem a vojenským konfliktem tím, že vyslaly do oblasti vojenskou misi vedenou Spojenými národy pod vlajkou UNOMI, „Operation Restore Hope“ (Operace ke znovuzískání naděje) a UNOSOMII, která zde působila od dubna 1992 do března 1995. Podle Rezoluce Rady bezpečnosti Spojených národů č. 751 (z 24. dubna 1992) byla tak do Somálska vyslána UNOSOM, aby umožnila předání humanitární pomoci. ${ }^{87}$ Jednalo se o misi v počtu 500 osob vojenského personálu, což bylo příliš málo na to, aby mohla obsáhnout velké území a pomoci obrovskému počtu lidí, kteří čelili humanitárním problémům. Proto v prosinci 1992 iniciovaly Spojené národy misi Operation Restore Hope (rovněž známou pod označením United Task Force, nebo UNITAF), v jejímž rámci bylo do oblasti za stejným účelem přepraveno 37000 př́slušníků jednotek. Mise United Task Force byla omezena na pouhých 5 měsíců a jejím hlavním cílem byla ochrana potravinové pomoci. V květnu 1993 ji vystř́idala mnohonárodnostní mírová operace UNOSOMII, ta byla zř́zena na základě rezoluce 814 Rady bezpečnosti.

Dne 5. června 1993 přepadli muži generála Muhammada Faraha Aideeda ze zálohy kontingent pákistánských vojáků, $24 \mathrm{z}$ nich zabili a mnoho dalších zranili. Od této chvíle se operace dostala do kritické situace; následujícího dne přijala Rada bezpečnosti rezoluci 837, která jasně požadovala zatčení a soud s těmi, kdo byli za incident odpovědní. To, co začalo jako nestranná mírová operace, jejímž cílem bylo nasytit hladovějící ženy a děti, se brzy změnilo v neúspěšný hon na generála Muhammada Aideeda, který vyvrcholil v noci ze 3. října, kdy bylo zabito 18 a zraněno 77 amerických armádních rangerů po útoku na shromaždiště generála Aideeda v Mogadišu. Seznam somálských ztrát byl ovšem ještě mnohem vyšší: odhadem bylo zabito 300 osob a 700 jich bylo zraněno, přičemž až $30 \%$ z tohoto počtu obětí byly ženy a děti. Jedná se o nejkrvavější konfrontaci v dějinách operací podniknutých Spojenými národy a tato událost byla začátkem i koncem celé mise. Na základě tlaku veřejnosti prezident Clinton přislíbil, že všichni američtí vojáci se vrátí domů do března 1994 a Rada bezpečnosti Spojených národů určila jako konečné datum operace UNOSOMII březen 1995. Operace „doklopýtala“ podle plánu do svého konce, aniž by dovršila politickou rekonstrukci, odzbrojila frakce či vyřešila konflikt, což byly původně stanovené cíle zásahu. Somálci byli ponecháni, aby si své problémy vyřešili sami.

\section{Konference v Artě a vytvoření přechodné národní vlády}

Prezident Džibutska Ismail Omar Gelle (Somálec z Džibutska) svolal v roce 2000 mírovou konferenci somálských vůdců s cílem vyřešit politické konflikty, které mezi sebou

87 Hippel [2000: 16]. 
navzájem měli. Návrh byl podporován Mezivládním úřadem pro rozvoj (Inter Government Authority for Development (IGAD), jednotlivými zeměmi (Džibutsko, Etiopie, Súdán, Keňa, Uganda) a rychle potvrzen USA, Itálií, Egyptem a Libyí. Evropská unie a Spojené národy plán rovněž podpořily. Delegáti se sešli na malém návrší u Arfy západně od města Džibuti, přičemž účastníci konference zastupovali široké spektrum klanů napříč sociálními třídami, tedy to, co se optimisticky nazývalo „občanská společnost“ (jmenovitě tradiční starší, náboženští učenci, intelektuálové, umělci a ženy). Válečníci byli z konference vyloučeni, protože nebyli považování za mírotvůrce. Hlavními aktéry na této konferenci tak byli starší reprezentující své klanové př́ílušníky a jednající se svými kolegy v tradičním stylu ve stínu velkého stromu. ${ }^{88}$ Konference trvala od ledna do 13. srpna 2000 a ve svém závěru určila přechodné národní shromáždění a prezidenta, který jmenuje prozatímní národní vládu (Transitional National Government - TNG); dále připravila prozatímní ústavu, jež do značné míry kopírovala vysoce centralizovanou vládu Siyad Barreho.

Abdulqassim Salad Hassan (z klanu Hawiye), bývalý ministr vnitra, byl zvolen prezidentem. Vzhledem k tomu, že Spojené národy od samého počátku konferenci podporovaly, uznaly novou vládu a uvítaly jejího zástupce na místě Somálska v Generálním shromáždění. Proti prozatímní národní vládě se však postavili váleční magnáti, takže do dvou let nebyla schopna ovládat ani Mogadišu. V březnu 2001 založili přední váleční magnáti konkurenční koalici nazvanou Somálská rada pro usmíření a obnovu (Somali Reconciliation and Restoration Council), ${ }^{89}$ jež měla své sídlo v rahanweynské zemědělské oblasti v Baidoa, která byla za etiopské pomoci osvobozena z vlivu generála Muhammada Faraha Aideeda (Hawiye) Rahanweynskou armádou odporu, ve skutečnosti místní domobranou, zformovanou v roce 1995.

Somálská rada pro usmíření a obnovu byla organizována etiopskou vládou s cílem oponovat Somálské prozatímní národní vládě zvolené na konferenci v Artě v Džibuti a vzhledem k tomu, že byla projektem etiopské vlády, konaly se její schůze v Awasa (město v jižní Etiopii). Vedena vůdcem Puntlandu Abdillahem Yusufem navrhovala uspořádat velkou smírčí konferenci uvnitř Somálska a naléhala na Abduqassima, aby se jí zúčastnil na obyčejné úrovni a ne jako prezident vlády, kterou váleční magnáti neuznávají.

Na závěr konference byl ustaven Prozatímní parlament, jenž zvolil plukovníka Abdillahi Yusufa Ahmeda, typického válečníka nepopulárního na většině somálského území, za prozatímního prezidenta. Prezident ihned jmenoval Ali Mohammada Geediho, veterána a občanského aktivistu, premiérem a ten pak na počátku prosince 2004 sestavil početný kabinet s velkou převahou Yusufových prŕvrženců a pošpiněný údajným etiopským zasahováním. Somálský prozatímní prezident zůstává vysoce kontroverzní osobou; Yusufovi zastánci jej líčí jako rozhodného nacionalistu a státníka, jeho odpůrci v něm vidí rodícího se diktátora, omezeného lokálního vůdce klanu a nevýznamného „sloupkaře“ sousední Etiopie. ${ }^{90}$ Podle profesora K. Menkhause, jednoho z nejlepších odborníků na součastnou politiku Somálska a př́mého pozorovatele voleb „prezidenta “, zaplatila etiopská vláda, a to od 3000 \$ do 5000 \&a každý hlas pro Yusufa. ${ }^{91}$ Pro většinu Somálců, kteří nejsou ani jeho příznivci, ani jeho odpůrci, představuje zvolení Yusufa nikoli národní konsensus, ale spíše

\footnotetext{
${ }^{88}$ Lewis [1999: 196-241], Anonymus [2002: 252].

89 Lewis [2002: 302].

90 African Report No 88: 1 [International Crisis Group 2002].

91 Menkhaus [2007: 361].
} 
vítězství jedné skupiny v dlouhodobé občanské válce. Prozatímní federální parlament je přitom velmi slabý vzhledem ke svému vnitřnímu rozdělení.

Dosud nejkontroverznějším činem prozatímního prezidenta byla jeho žádost o vojenskou podporu ze strany Africké unie, konkrétně v počtu 20000 mužů, jež by pomohla jeho vládě získat autoritu v rámci Somálska. To bylo všeobecně považováno za znamení, že Yusuf je připraven svou moc vnucovat silou, pokud by to bylo nutné - což je velmi nepopulární představa. Yusuf ovšem nebyl schopen tuto podporu ze strany Africké unie získat, a tak se přestěhoval z Keni nikoli do hlavního města Somálska, nýbrž do městečka nedaleko etiopských hranic - do Baidoa.

V druhé polovině roku 2006 se v Mogadišu zrodila další síla. Touto silou byla Unie islámského soudního dvora (Union of Islamic Court) tvořená 11 místními islámskými soudními dvory, které působily od počátku 90. let jako právní orgán založený na islámském právu a namířený proti zločincům. Od června 2006 už kontrolovala Unie všechny části Mogadiša a přinesla s sebou do města mír a pořádek. Unie islámského soudního dvora následně rozšířila svou působnost na většinu jižního Somálska, a sjednotila tak tuto oblast pod jedním vedením..$^{92}$ Ve své zahraniční politice opakovala totéž heslo jako předchozí vlády - spojit všechna somálská území, která jsou ovládána Etiopií a dalšími státy. Etiopská vláda z tohoto důvodu vyslala 40000 vojáků, aby podpořili Prozatímní federální vládu Somálska a zničili Unii islámského soudního dvora. Po těžkých bojích proto Dvůr v prosinci 2006 rozpustil své členy, kteří se reorganizovali jako guerilloví bojovníci. Prozatímní federální vláda Somálska se potom z Baidoa přestěhovala na palubě etiopských vojenských letadel do Mogadiša; ještě v roce 2007 probíhaly těžké boje mezi etiopskou armádou a islamistickými povstalci. ${ }^{93}$

Je velmi těžké předpovědět, co se v blízké budoucnosti se Somálskem stane; Somálci se sice dokázali sjednotit proti svému historickému nepř́teli Etiopii, ale poté, co Etiopie oficiálně stáhla své jednotky ze Somálska koncem roku 2009, se prozatím nedokázali dohodnout na vytvoření centrální vlády své země.

\section{Závěr}

Oblast Afrického rohu je v druhé polovině 20. století jednou z válečnými konflikty nejvíce zdevastovaných částí světa. Pokusil jsem se z historického a sociologického hlediska analyzovat kořeny těchto válek od doby kolonializmu až do současnosti; rozbor zahrnuje roli USA a Sovětského svazu během studené války, rozpad socialistického bloku, vládu Siyad Barreho v Somálsku, transformaci konfliktu v Somálsku po roce 1991 i proces ukončení války v jižním Súdánu. Jak tato studie ukazuje, kořeny těchto konfliktů vycházejí z koloniálního období, kdy cizí mocnosti okupovaly a implantovaly autoritativní administrativní struktury, které nemají nic společního s politickými kulturami lidí na okupovaných teritoriích. Válečný konflikt v jižním Súdánu, jenž trval více než půl století, vypukl před koncem britské koloniální nadvlády a na svůj účet si připsal životy několika milionů civilních obyvatel. Na základě historických dokumentů jsem ukázal, že válečný konflikt v Súdánu měl regionální i globální souvislosti. Z globálního hlediska v průběhu studené

92 Africa Report No. 116 [International Crisis Group 2006].

93 The Economist [April 7th-13th, 2007]. 
války podporovaly Sovětský svaz a USA válečné skupiny bojující v těchto konfliktech. Po konci studené války se sice vnější podpora válečného konfliktu změnila, ale pokračovala jiným způsobem: súdánská vláda měla všestrannou oporu $\mathrm{z}$ arabské části světa a z Íránu a SPLA ze subsaharské Afriky a z USA. Somálsko tak představuje typický př́klad toho, jak koloniální mocnosti (Británie, Etiopie, Francie a Itálie) rozdělily území jednoho národa do pěti koloniálních území, a čímž znemožnili Somálcům, aby mohli budovat svůj vlastní stát zahrnující všechna jejich území. Velkou chybou je i koloniální vztah mezi etiopským státem a somálským národem; Etiopie kolonizovala své sousední národy koncem 19. století, ve stejné době jako kolonialisté ze západní Evropy. Velkou politickou otázkou zůstává, proč Etiopie nebyla uznána jako koloniální stát a byla nucena opustit somálské území jako ostatní koloniální mocnosti. Z mého hlediska jsou kolonialisté nejenom Západoevropané, jak nám totiž ukázaly dějiny, Asiaty kolonizovali Asiaté a Afričany kolonizovaly sousední národy jako třeba právě Etiopie. Zdrojem konfliktu v Somálsku tudíž zůstává vztah mezi Somálskem a Etiopií. Nakonec platí, že současný svět je globalizován více než v minulosti, a proto všechny válečné konflikty na světě potřebují globální řešení.

\section{Literatura}

Abdi, Mohamed Mohamud. [2007]. A History of Ogaden (Western Somalia) Struggle for Self-Determination. UK: Lightning Source.

Achebe, Chinua. [2003]. Home and Exile. Edinburgh, New York, Melbourne: Canon gate.

Achebe, Chinua. [1959]. Things fall apart. New York: Fawcett Crest.

Agreement between Eritrea \& Ethiopia, 12. 12. 2000, Algiers (Algeria).

Arop, Madut Arop. [2006]. Sudan's painful road to peace: A full story of the founding and development of SPLM/SPLA. Bez místa vydání: Book Surge, LLC.

Author Anonymous. [2002]. Government recognition in Somalia and regional political stability in the Horn of Africa. Journal of Modern African Studies 40 (2), s. 247-272.

Beshir, Mohamed Omer. [1968]. The Southern Sudan: Background to Conflict. London: C. Hurst and Co. Bulatovich, Alexander. [(1900) 2000]. Ethiopia through Russian Eyes: Country in Transition 1896-1898. Translated and Edited by Seltzer Richard. Lawrenceville, NJ \& Asmara Eritrea: The Red Sea Press, Inc.

Bulcha, Mekuria. [2002]. The Making of Oromo Diaspora: A Historical Sociology of Forced Migration. Minneapolis, Minnesota: Kirk House Publishers.

Castagno, Alphonso A., jr. [1966]. Somali Republic. In. Coleman, S. J. - Rosberg, C. G., jr. (eds). Political Parties and National Integration in Tropical Africa. Berkley and Los Angeles: University of California Press.

Chabal, Patrick. [2009]. Africa: The Politics of Suffering and Smiling. London \& New York: Zed Books.

Chege, Michael. [2008]. Kenya: Back from the brink. Journal of Democracy (October 2008), Volume 19, No. 4, s. 125-139.

Clapham, Christopher. [1988]. Transformation and Continuity in Revolutionary Ethiopia. Cambridge: Cambridge University Press.

Comprehensive Peace Agreement (CPA)Between the Government of The Republic of The Sudan and The Sudan People's Liberation Movement / Sudan People's Liberation Army. http://www.aec-sudan.org /docs/cpa/cpa-enpdf [1. 12. 2011].

Counter-terrorism in Somalia: losing hearts and Minds? [2005]. African Report No. 95 - 11 July 2005.

Daly, M. W. [2007]. Darfur's Sorrow: A History of Destruction and Genocide. Cambridge: Cambridge University Press.

Deng, Francis M. [2010]. Sudan: A Case of Mismanaged Diversity. In. Deng, Francis M. (ed.). Self-Determination and National Unity: A Challenge for Africa. Trenton, NJ \& Asmara, Eritrea: Africa World Press, Inc.

Deng, Francis, Mading. [1972]. The Dinka of the Sudan. Long Grove, Illinois: Waveland Press. 
Deng, Francis. [1973]. Dynamics of Identification, a Basis for National Integration in the Sudan. Sudan: Khartoum University Press.

Deng, M. Francis. [1991]. War of Vision for the Nation. In. Voll, John O. (ed.) Sudan: the State and Society in Crisis. Bloomington and Indianapolis: Indiana University Press.

Douglas, H. Johnson. [2003]. The Root Cause of Sudan's Civil Wars. Oxford: James Currey.

Drysdale, John. [1964]. The Somali Dispute. London and Dunmow: Pall Mall Press.

Ehret, Christopher. [2002]. The Civilizations of Africa: A History to 1800. Charlottesville: University of Virginia.

Elkins, Caroline. [2005]. Britain's Gulag: The brutal end of Empire in Kenya. London: Pimlico.

Fact book. [2010]. https://www.cia.gov/library/publications/the-world-factbook/.

Gadaa, Melba. [1980]. Oromia: A brief Introduction. Oromia: Finfine.

Garang, John. [1992]. The call for Democracy in Sudan. Edited and Introduced by Khalid Mansour. London and New York: Kegan Paul International.

Healy, Sally. [2008]. Lost opportunities in the Horn of Africa: How Conflicts Connected and Peace Agreements Unravel. London: Chatham House.

Henze, Paul, B. [2001]. Layers of Time: A History of Ethiopia. London: Hurst \& Company.

Hill, Richard. [1959]. Egypt in the Sudan: 1820-1881. Oxford: Oxford University Press.

Hippel, K. von. [2000]. Democracy by Force: US Military Intervention in the Post-Cold War World. Cambridge: Cambridge University Press.

Human Rights Watch. [2008]. "So Much Fear": War Crimes and Devastation of Somalia. New York: Human Rights Watch.

Iliffe, John. [2001]. Afrika a Afričané: Dějiny kontinentu. Praha: Vyšehrad.

International Crisis Group. [2002]. God, Oil and Country: Changing the logic of War in Sudan. African Report No. 39. Brussels, Belgium.

International Crisis group. [2003]. Negotiating a Blueprint for peace in Somalia. African Report No. 59 Mogadishu/Brussels.

International Crisis Group. [2003]. Somaliland: Democratization and its Discontent. African Report No. 66. Nairobi/Brussels.

International Crisis Group. [2006]. Can the Somali crisis be contained? African Report No. 116. Nairobi/ Brussels.

International Crisis Group. [2007]. Somalia: The tough part is ahead. Policy Briefing Africa: Briefing No. 45. Nairobi/Brussels.

International Crisis Group. [2004]. Somalia: Continuation of War by other means? Africa: Report No. 88 Nairobi/Brussels.

Iyob, Ruth. [1995]. The Eritrean Struggle for Independence: Domination, resistance, nationalism, 1941-1993. Cambridge: Cambridge University Press.

Kumsa Alemayehu. [2010]. Two Faces of Somalia. In. Chabal, Patrick - Skalník, Peter, (eds.). Africanists on Africa: Current Issues. Berlin: Dr. W. Hopf.

Kumsa, Alemayehu. [1992]. Sociologické problémy státu, moci a politiky. (Diplomová práce). Praha: Filozofická fakulta Univerzity Karlovy v Praze.

Lewis, I. M. [1999]. A Pastoral Democracy: A study of Pastoralism and the politics among the Northern Somali of the Horn of Africa. Oxford: James Currey.

Lewis, I. M. [2002]: A Modern History of the Somali. Revised, Updated \& Expanded. Oxford: James Currey. Mann, Michael. [1984]. The Autonomous power of the State. Archives Européennes de sociologie 25, pp. 185-213.

Mann, Michael. [2007]. The Sources of Social Power. Volume 1. A history of power from the beginning to A.D. 1760. Cambridge: Cambridge University Press.

Marcus, Harold, G. [1994]. A History of Ethiopia. Berkeley: University of California Press.

Menkhaus, Ken. [2004]. Somalia: State collapse and the Threat of Terrorism. ADELPHI PAPER 364. Oxford: Oxford University Press.

Menkhaus, Ken. [2007]. There and Back Again in Somalia. http://www.zcommunications.org/there-and -back-again-in-somalia-by-ken-menkhaus [1. 12. 2011].

Murdock, George, Peter. [1959]. Africa: Its Peoples and Their Cultural History. New York McGraw-Hill Company, Inc.

Nairobi, 15-17 March 1999. Conference Documentation, pp. 181-198. 
Ndulo Muna. [2010]. Ethnic diversity: A Challenge to African Democratic Governance. In. Deng, Francis M. (ed.). Self-Determination and National Unity: A Challenge for Africa. Trenton, NJ \& Asmara, Eritrea: Africa World Press, Inc.

Negash, Tekeste - Kjetil, Tronvoll. [2000]. Brothers at war: Making sense of the Eritrean- Ethiopian War. Oxford: James Currey.

Pankhurst, Richard. [1968]. Economic History of Ethiopia: 1800-1935. Addis Ababa: Haile Sellassie University Press.

Prendergast, John - Thomas-Gensen, Colin. [2007]. Blowing the Horn. In. Foreign Affairs Volume 86 No. 2, March/April 2007 pp. 59-74.

Prunier, Gérard. [1995]. Somalia: Civil War, Intervention and Withdrawal 1990-1995 (July 1995). REFWORLD. http://www.unhcr.org/refworld/country,,WRITENET,,SOM,,3ae6a6c98,0.html.

Robertson, James W. [1974]. Transition in Africa: from Direct Rule to Independence. London \& Khartoum. Sagalee Haaraa No. 33, May 2001. Organ of London based Oromia Support Group.

Salviac, De Martial. [2008 (1901)]. An Ancient People: The Oromo, Great African Nation. Finfinnee: Oromia Culture and Tourism Bureau.

Samatar, Abdi Ismail. [1999]. Somalia: Investing in Shared Institutions \& Values. In. Networking with Views to Promoting Peace. Conflict in the Horn of Africa: what can civil society do to bring about solidarity and cooperation in the region?

Samatar, Abdi Ismail. [2007]. Warlordism, Ethiopian invasion, Dictatorship, \& America's role. http://www .hiiraan.com/op4/2007/feb/2120/somalia_warlordism,_ethiopian_invasion,_dictatorship,_america -\%E2\%80\%99s_role.aspx

Sidahmen, Abdel Salam. [1997]. Politics and Islam in Contemporary Sudan. London: Palgrave Macmillan. Somalia: A failed state that threatens the region. The Economist, April 7-13 2007, p. 37.

Tareke, Gebru. [2009]. The Ethiopian Revolution: War in the Horn of Africa. New Haven \& London: Yale University Press.

Totten, Samuel - Markusen, Eric (eds). [2006]. Genocide in Darfur: Investigating the Atrocities in the Sudan. New York \& London: Routledge.

Touval, Saadia. [1963]. Somali Nationalism: International Politics and Unity in the Horn of Africa. Cambridge, Massachusetts: Harvard University Press.

Voll, John O. [1991]. Sudan: State and society in crisis. Washington D.C.: Middle East Institute.

Wai, Dustan M. [1973]. The Southern Sudan: The country and the People. In. Wai, Dustan M. (ed.). The Southern Sudan: The Problem of National Integration. London: Frank Cass.

Wodajo, Kifle. [1999]. Conflicts, States and Societies in the Horn of Africa. In. Conflict in the Horn of Africa: what can civil society do to bring about solidarity and cooperation in the Region. Nairobi, 15-17 March 1999. Conference Documentation. Addis Ababa, Ethiopia: The Heinrich Böll Foundation, Regional Office Horn of Africa, pp. 103-116.

Záhořík, Jan. [2009]. Etiopie v letech 1923-1935: Cesta k italské invazi. Praha: Karolinum.

Alemayehu Kumsa (1961) se narodil v Oromii (Etiopie). V České republice vystudoval na Filozofické fakultě Univerzity Karlovy obor sociologie. Vyučuje sociologii, politickou antropologii, etnologii Afriky a politické konflikty v současném světě. Zabývá se problémy budování státu, národní identitou a válečnými konflikty. 